\section{Carbon storage and nitrous oxide emissions of cropping systems in eastern Washington: A simulation study}

\author{
C. Stöckle, S. Higgins, A. Kemanian, R. Nelson, D. Huggins, J. Marcos, and H. Collins
}

\begin{abstract}
Conservation tillage is an agricultural strategy to mitigate atmospheric greenhouse gas (GHG) emissions. In eastern Washington, we evaluated the long-term effects of conventional tillage (CT), reduced tillage (RT) and no-tillage (NT) on soil organic carbon (SOC) storage and nitrous oxide $\left(\mathrm{N}_{2} \mathrm{O}\right)$ emissions at three dryland and one irrigated location using the cropping systems simulation model CropSyst. Conversion of CT to NT produced the largest relative increase in SOC storage $(\triangle \mathrm{SOC}$, average yearly change relative to $\mathrm{CT})$ in the top $30 \mathrm{~cm}$ (11.8 in) of soil where $\Delta$ SOC ranged from 0.29 to $0.53 \mathrm{Mg} \mathrm{CO}_{2} \mathrm{e} \mathrm{ha}^{-1} \mathrm{y}^{-1}\left(\mathrm{CO}_{2} \mathrm{e}\right.$ is carbon dioxide $\left[\mathrm{CO}_{2}\right]$ equivalent of SOC; 0.13 to 0.24 tn $\left.\mathrm{CO}_{2} \mathrm{e} \mathrm{ac}^{-1} \mathrm{yr}^{-1}\right)$. The $\Delta \mathrm{SOC}$ were less with lower annual precipitation, greater fallow frequency, and when changing from CT to RT. Overall, $\triangle$ SOC decreased from the first to the third decade after conversion from CT to NT or RT. Simulations of $\triangle \mathrm{SOC}$ for the conversion of CT to NT based on a 0 to $15 \mathrm{~cm}$ ( 0 to $5.9 \mathrm{in}$ ) soil depth were greater than the $\triangle \mathrm{SOC}$ based on a 0 to $30 \mathrm{~cm}$ depth, primarily due to differences among tillage regimes in the depth-distribution of carbon $(C)$ inputs and the resultant SOC distribution with depth. Soil erosion rates under CT in the study region are high, posing deleterious effects on soil quality, productivity, and aquatic systems. However, an analysis that includes deposition, burial, and sedimentation on terrestrial and aquatic systems of eroded SOC indicates that the substantial erosion reduction obtained with RT and NT may result only in minor additional SOC oxidation as compared to CT. Simulated $\mathrm{N}_{2} \mathrm{O}$ emissions, expressed as $\mathrm{CO}_{2}$ equivalent, were not very different under CT, RT, and NT. However, $\mathrm{N}_{2} \mathrm{O}$ emissions were sufficiently high to offset gains in SOC from the conversion of CT to RT or NT.Thus, reducing tillage intensity can result in net C storage, but mitigation of GHG is limited unless it is coupled with nitrogen $(\mathrm{N})$ fertilizer management to also reduce $\mathrm{N}_{2} \mathrm{O}$ emission.
\end{abstract}

Key words: CropSyst—greenhouse gases emission—nitrous oxide—-simulation model—soil organic carbon-tillage

\begin{abstract}
Numerous researchers have investigated how agricultural practices can increase soil organic carbon (SOC) storage by reducing the $\mathrm{SOC}$ turnover rate or increasing residue input rates (Bruce et al. 1999; Lal et al. 1999; Allmaras et al. 2000; Deen and Kataki 2003). Tillage operations that mix crop residues with soil and decrease soil aggregation facilitate microbial degradation of soil organic matter (Balesdent et al. 2000; Six et al. 2004a). Therefore, a shift from high physical disturbance conventional tillage (CT) to reduced tillage (RT) to no-tillage (NT) can increase SOC storage (Allmaras et al. 2000; Huggins et al. 2007). Crop rotations
\end{abstract}

of mineral $\mathrm{N}$ for $\mathrm{N}_{2} \mathrm{O}$ production can help mitigate $\mathrm{N}_{2} \mathrm{O}$ emissions.

In eastern Washington, a steep east to west precipitation gradient occurs, and dryland farmers use a wide array of wheat (Triticum aestivum L.)-based crop rotations, from continuous annual cropping (high rainfall, high yields) to wheat-fallow (low rainfall, low yields every other year), thereby producing varying amounts of crop residues available as potential input to SOC and soil moisture patterns. Consequently, the potential for SOC storage is not uniform, and despite the availability of a few studies (Granatstein et al. 1987; Fuentes et al. 2004), the C storage benefit of the conversion from CT to NT in the region is still not well defined (Brown and Huggins 2012).

The benefit in SOC storage from the conversion of CT to either RT or NT depends on changes in storage due to reduced tillage intensity. This change is difficult to measure and document in standard ways to allow proper comparisons. For example, Baker et al. (2007) pointed out that the positive rates of SOC storage usually attributed to the conversion to NT were based on comparing only the surface soil depths where indeed NT stores more SOC than CT (West and Post 2002). Differences in SOC, however, can be diminished or may be considered negligible when deeper depth increments of soil are assessed since inversion tillage mixes and distributes residue $\mathrm{C}$ inputs and SOC to soil depths throughout the tillage zone (Angers et al. 1997; Baker et al. 2007). The fate of SOC below the tillage zone is less understood. There are indications that, in the inland Pacific Northwest, dryland cropping systems may be steadily losing subsoil $\mathrm{C}$ that

Claudio Stöckle is professor and chair and Stewart Higgins and Roger Nelson are research associates of the Department of Biological Systems Engineering, Washington State University, Pullman, Washington. Armen Kemanian is an assistant professor of the Department of Plant Science, The Pennsylvania State University, University Park, Pennsylvania. David Huggins is a soil scientist with the USDA Agricultural Research Service Land Management and Water Conservation Research Unit, Pullman, Washington. Javier Marcos is a postdoctorate researcher at the Blackland Research and Extension Center, Texas A\&M University, Temple, Texas. Harold Collins is a researcher with the USDA Agricultural Research Service Vegetable and Forage Crops Research Laboratory, Prosser, Washington. 
accumulated prior to agricultural conversion of native vegetation (Rasmussen et al. 1998; Kemanian and Stockle 2010).

It is unclear whether conversion from CT to NT will have an overall effect on emissions of $\mathrm{N}_{2} \mathrm{O}$, a powerful GHG (with $\sim 300$ times larger global warming potential than carbon dioxide $\left[\mathrm{CO}_{2}\right]$ on a mass basis). Six et al. (2004b) concluded after reviewing published comparisons that $\mathrm{N}_{2} \mathrm{O}$ fluxes were higher under NT than $\mathrm{CT}^{2}$ in drier environments, but the trend eventually reversed in humid climates. Other researchers have found evidence for lower $\mathrm{N}_{2} \mathrm{O}$ emissions from NT compared to CT (Kroeze et al. 1999; Chatskikh and Olesen 2007). These studies illustrate the situation-specific nature of cropping system impacts on SOC storage and $\mathrm{N}_{2} \mathrm{O}$ emissions and show that it is important to closely evaluate the conditions under which the conclusions of various studies were drawn.

In this study, we use process-oriented simulation modeling to assess the long-term effects of CT, RT, and NT on SOC storage and $\mathrm{N}_{2} \mathrm{O}$ emissions for four important dryland cropping systems and one irrigated cropping system in eastern Washington State. Our ultimate goal is to quantitatively assess the impact of crop and tillage practices on the net GHG emissions from major agricultural systems in the region.

The Cropping Systems Model. For this study we used the CropSyst model (Stöckle et al. 1994; Stöckle et al. 2003). CropSyst is a multiyear, multicrop, daily time step cropping systems simulation model developed to study the effect of climate, soils, and management strategies on cropping systems productivity and the environment. The model has been evaluated and used extensively in the US Pacific Northwest (Pannkuk et al. 1998; Peralta and Stöckle 2002) and in many world locations (Pala et al. 1996; Monzon et al. 2006; Wang et al. 2006).

Simulating the fate of organic C and N is challenging because the annual fluxes to and from the soil organic $\mathrm{C}$ and $\mathrm{N}$ pools are small in relation to total pool sizes, roughly within $2 \%$ of the pool size. In addition, although changes of SOC are noticeable in a decadal time frame, submonthly, daily, or hourly changes on the availability of mineral $\mathrm{N}$ are important to drive crop growth and determine $\mathrm{N}$ losses, including $\mathrm{N}_{2} \mathrm{O}$ emissions. To accommodate these dynamics, it has been customary to separate organic $\mathrm{C}$ and
$\mathrm{N}$ into pools with different turnover rates, an approach that can be traced back to the PHOENIX model (McGill et al. 1981). Each pool decomposes due to microbial attack at different rates assumed to be dependent on SOC chemical recalcitrance and physical protection. Usually, there is a soil pool with a slow turnover rate (several decades to centuries) that serves as the backbone of SOC (40\% to $70 \%$ of SOC), a pool with a faster turnover rate that accommodates $\mathrm{C}$ gains or losses and measurable oscillations in the $\mathrm{C}: \mathrm{N}$ ratio within a decade, and other faster cycling pools (e.g., microbial biomass). This is an attempt to present the continuum of turnover rates of organic compounds in the soil in discrete form that is amenable for model parameterization. An important fraction of the $\mathrm{C}$ lost from a pool during SOC oxidation leaves the soil as $\mathrm{CO}_{2}$ from microbial respiration, and the remainder is transferred to the microbial biomass pool or another C pool. A similar framework is applied to fresh residues. When the turnover rates are independent of the pool size, these models are generically described as coupled linear models. The CENTURY model (Parton et al. 1988; Parton et al. 1994) is probably one of the most well-known of this family of models. Another example is the Verberne model, which was designed to simulate SOC dynamics using a multiple pool approach based on previous efforts presented in van Veen and Paul (1981) and van Veen et al. (1984). When the turnover rates are dependent on the pool size, the models are coupled nonlinear, an approach followed in Kemanian and Stockle (2010) and Kemanian et al. (2011). Reviews of models for estimating SOC dynamics have been presented by Powlson et al. (1996), Molina and Smith (1998), and Shaffer et al. (2001).

The Soil Organic Carbon and Nitrogen Submodel. To simulate $\mathrm{C}$ and $\mathrm{N}$ dynamics in CropSyst, we mostly followed the structure of the Verberne model (Verberne et al. 1990) as shown in the diagram presented in figure 1. The pools included in the model and their $\mathrm{C} / \mathrm{N}$ ratios are presented in table 1 , with a separate set of pools defined for each soil layer. Microbial-driven C loss from organic residues and soil organic matter follow firstorder kinetics with the rate constants shown in table 1. A nonmicrobial residue decomposition rate was added to account for physical comminution of surface residue. Except for the stable pool, the rate constants in table 1 are similar to those proposed in Whitmore et al. (1997). The stable pool turnover rate constant was set after several one hundredyear runs for CT practice for all locations/ cropping systems in this study (see below) so as to obtain a fraction of stable SOC of $50 \%$ to $70 \%$ of the total SOC (Collins et al. 2000) at steady state. The resulting value is within the range given by Whitmore et al. (1997), Verberne et al. (1990), and (Parton and Rasmussen 1994).

Most of the organic $\mathrm{C}$ removed from a pool is lost as $\mathrm{CO}_{2}$, and the rest is transferred to other pools (figure 1) according to the transfer coefficients presented in table 2, where $\mathrm{T}_{\mathrm{X} \rightarrow \mathrm{Y}}$ represents the fraction of $\mathrm{C}$ transferred from pool $X$ to pool Y. Other abbreviations are as in table 1 . Because physical protection of SOC is greater in clay than in sand soils, the Verberne model provides specific constants to represent the relative partitioning of SOC transfer from the microbial pool to the labile (not protected) and metastable (protected) pools for sand and clay soils. This set of fixed values was replaced by a function that depends on the sand concentration and allows for a gradual change of partitioning across soil types (table 2). The higher the sand concentration, the lower the fraction of the stabilized microbial $\mathrm{C}$ biomass destined for the metastable pool and the higher the fraction destined for the labile pool.

The C transferred among pools also determines the $\mathrm{N}$ transferred, which is calculated as the amount of $\mathrm{N}$ required to match the $\mathrm{C}: \mathrm{N}$ ratio of the receiving pools. In this process, if the amount of $\mathrm{N}$ released by the decomposing pool is greater than the amount of $\mathrm{N}$ required by the receiving pools, mineral $\mathrm{N}$ in the form of ammonium $\left(\mathrm{NH}_{4}\right)$ is released to the soil layer (mineralization). If the opposite is true, $\mathrm{NH}_{4}$ (first source) and nitrate $\left(\mathrm{NO}_{3}\right)$ (secondary source) from the soil layer is taken up for microbial consumption (immobilization). If soil mineral $\mathrm{N}$ is insufficient to supply the microbial demand, the decomposition is reduced in all pools proportionally to the fraction of the $\mathrm{N}$ demand met by the available soil mineral $\mathrm{N}$. There is no biological transfer of $\mathrm{NH}_{4}$ or $\mathrm{NO}_{3}$ among soil layers.

CropSyst includes calculations to estimate $\mathrm{N}$ uptake, $\mathrm{N}$ movement with water, $\mathrm{N}$ interaction with the soil matrix, and $\mathrm{N}$ transformations. Nitrous oxide emissions from denitrification are modeled based on concepts and data from del Grosso et al. (2000) 


\section{Figure 1}

Pools and carbon flows of the soil organic carbon (SOC) submodel in CropSyst (fcr $=$ fast-cycling residue pool, $\mathrm{scr}=$ slow-cycling residue pool, $\mathrm{Ir}=$ lignified residue pool, $\mathrm{MB}=$ microbial biomass pool, $\mathrm{L}=$ labile SOC pool, MS = meta stable SOC pool, and S = stable SOC pool).

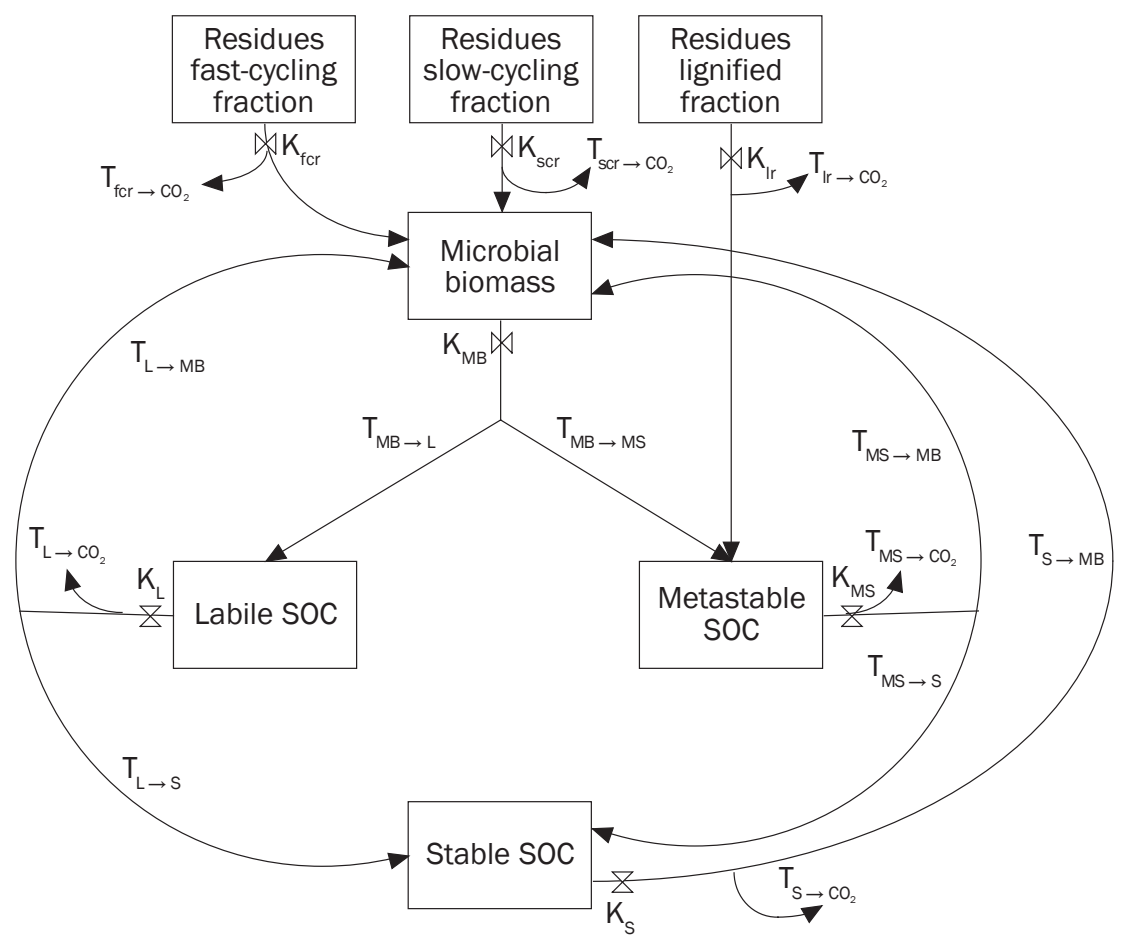

Table 1

Carbon pools that are modeled in CropSyst in each soil layer.

\begin{tabular}{llll}
\hline Description & Abbreviation & C/N ratio & Turnover rate $\left(\mathbf{d}^{-\mathbf{1}}\right)$ \\
\hline Fast-cycling organic residue & $\mathrm{fc}_{\mathrm{r}}$ & 10 & 0.2 \\
Slow-cycling organic residue & $\mathrm{sc}_{\mathrm{r}}$ & Variable & 0.1 \\
Lignified organic residue & $\mathrm{I}_{\mathrm{r}}$ & 100 & 0.02 \\
Microbial biomass & $\mathrm{MB}$ & 8 & 0.05 \\
Labile soil organic matter & $\mathrm{L}$ & 20 & 0.015 \\
Metastable soil organic matter & $\mathrm{MS}$ & 15 & 0.0009 \\
Stable soil organic matter & $\mathrm{S}$ & 10 & 0.000005 \\
\hline
\end{tabular}

Notes: $\mathrm{C}=$ carbon. $\mathrm{N}=$ nitrogen.

and Parton et al. (1996), who have developed a field-scale functional modeling approach that has been widely used. Briefly, the functional model describes actual denitrification $\left(\mathrm{D}_{\mathrm{a}}\right)$ as

$\mathrm{D}_{\mathrm{a}}=\mathrm{D}_{\mathrm{p}} \min \left(\mathrm{F}_{\mathrm{N}}, \mathrm{F}_{\mathrm{R}}\right) \mathrm{F}_{\mathrm{W}}$,

where $\mathrm{D}_{\mathrm{p}}$ is potential denitrification and $\mathrm{F}_{\mathrm{N}}$, $\mathrm{F}_{\mathrm{R}}$, and $\mathrm{F}_{\mathrm{W}}^{\mathrm{p}}$ are reduction functions (values from 0 to 1) depending on soil $\mathrm{NO}_{3}$, soil respiration, and soil water content, respectively. The $\mathrm{N}_{2} \mathrm{O}$ fraction of $\mathrm{D}_{\mathrm{a}}$ is also dependent on soil $\mathrm{NO}_{3}$, respiration, and water content as given by Parton et al. (1996). Nitrification is modeled as a first-order rate process using the formulation of SOILN (Wu and McGechan 1998), a model that has been used and tested in many studies (Meier et al.2006). Emissions of $\mathrm{N}_{2} \mathrm{O}$ due to nitrification are modeled as a fraction of nitrified $\mathrm{N}$ determined by a function of soil moisture and temperature (Maag and Vinther 1996).

The effect of tillage was calculated based on soil disturbance ratings (SDR) used by the US Department of Agriculture Natural
Resource Conservation Service (USDA NRCS 2002) to characterize a large number of field operations, including mechanical operations other than tillage (Kemanian and Stöckle 2010). Each operation is given a rating from 0 to 30. The lower SDR values are associated with operations that gently disturb the soil, and the higher SDRs (25 to 30) are associated with operations with greater soil disturbance, such as offset disking and moldboard plowing that aggressively break up soil aggregates and physically mix the soil. For each soil layer affected by a tillage operation, the cumulative SDR increases with each operation and decreases as a function of time and soil water content at a rate $2 \%$ per day for a soil at field capacity (Kemanian and Stöckle 2010). The SDR and the soil clay concentration or fraction are used to determine a tillage adjustment factor $\left(\mathrm{F}_{t}>\right.$ 1) that multiplies the SOC oxidation rate of all SOC pools in the layer. The adjustment factor is calculated as follows:

$\mathrm{F}_{\mathrm{t}}=1+\left[\mathrm{F}_{\mathrm{cx}}+\left(\mathrm{F}_{\mathrm{sx}}-\mathrm{F}_{\mathrm{cx}}\right) \exp \left(-5.5 \mathrm{f}_{\mathrm{clay}}\right)\right][1-$ $\left.\exp \left(-0.025 \mathrm{C}_{\mathrm{SDR}}\right)\right]$,

where $F_{t}$ is the SOC oxidation rate adjustment factor due to tillage, $F_{c x}$ is the maximum adjustment factor for clay soil, $\mathrm{F}_{\mathrm{sx}}$ is the maximum adjustment factor for sandy soil, $\mathrm{f}_{\text {clay }}$ is the soil clay fraction, and $\mathrm{C}_{\mathrm{SDR}}$ is the daily cumulative soil disturbance rate. The standard values for $\mathrm{F}_{\mathrm{cx}}$ and $\mathrm{F}_{\mathrm{sx}}$ are 0.5 and 1.5 , providing a turnover rate enhancement in this study of $\sim 1.8$ immediately after heavy tillage operations.

Although some studies of tillage effects on SOC storage are available (Conant et al.2007; La Scala 2008), the information is generally insufficient to provide specific guidance for modeling purposes. The approach of increasing SOC turnover rates to account for tillage effects is commonly used (Balesdent et al. 2000; Krull et al. 2003, Conant et al. 2007; Carvahlo Leite et al. 2004). Based on 17 years of field data, Balesdent et al. (2000) estimated that tillage provided an enhancement of more than twice the rate of no-tillage. $\mathrm{La}$ Scala et al. (2008) measured $\mathrm{CO}_{2}$ fluxes in four experimental plots and estimated an oxidization enhancement fluctuating from 1.27 to 2.6 due to tillage compared to notillage treatments.

Although the $\mathrm{C}$ and $\mathrm{N}$ submodel in CropSyst is based on modifications of the multipool modeling framework used in 


\section{Table 2}

Transfer coefficients for decomposing residue and oxidizing soil organic carbon (SOC) pools. $T_{X \rightarrow Y}$ represents the fraction of carbon transferred from pool $\mathrm{X}$ to pool $\mathrm{Y}\left(\mathrm{fcr}=\right.$ fast-cycling residue pool, $\mathrm{scr}=$ slow-cycling residue pool, $\mathrm{CO}_{2}=$ carbon dioxide, $\mathrm{Ir}=$ lignified residue pool, $\mathrm{MB}=\mathrm{microbial}$ biomass pool, $\mathrm{L}=$ labile SOC pool, $\mathrm{MS}=$ meta stable SOC pool, and $\mathrm{S}=$ stable SOC pool).

\begin{tabular}{|c|c|c|c|c|}
\hline Residue & Microbial & Labile & Metastable & Stable \\
\hline $\mathrm{T}_{\mathrm{fcr} \rightarrow \mathrm{CO}_{2}}=0.6$ & $\mathrm{~T}_{\mathrm{MB} \rightarrow \mathrm{MS}}=0.5 /\left[1+\left(\mathrm{f}_{\text {sand }} / 0.4\right)^{3}\right]$ & $T_{L \rightarrow S}=0.001$ & $\mathrm{~T}_{\mathrm{MS} \rightarrow \mathrm{S}}=0.01$ & $\mathrm{~T}_{\mathrm{S} \rightarrow \mathrm{CO}_{2}}=0.8$ \\
\hline $\mathrm{T}_{\mathrm{scr} \rightarrow \mathrm{CO}_{2}}=0.7$ & $\mathrm{~T}_{\mathrm{MB} \rightarrow \mathrm{L}}=1-\mathrm{T}_{\mathrm{MB} \rightarrow \mathrm{MS}}$ & $\mathrm{T}_{\mathrm{L} \rightarrow \mathrm{CO}_{2}}=0.75\left(1-\mathrm{T}_{\mathrm{L} \rightarrow \mathrm{S}}\right)$ & $\mathrm{T}_{\mathrm{MS} \rightarrow \mathrm{CO}_{2}}=0.8\left(1-\mathrm{T}_{\mathrm{MS} \rightarrow \mathrm{S}}\right)$ & $\mathrm{T}_{\mathrm{S} \rightarrow \mathrm{MB}}=1-\mathrm{T}_{\mathrm{S} \rightarrow \mathrm{CO}_{2}}$ \\
\hline $\mathrm{T}_{\mathrm{Ir} \rightarrow \mathrm{CO}_{2}}=0$ & $\mathrm{~T}_{\mathrm{MB} \rightarrow \mathrm{S}}=0$ & $T_{L \rightarrow M B}=0.25\left(1-T_{L \rightarrow S}\right)$ & $\mathrm{T}_{\mathrm{MS} \rightarrow \mathrm{MB}}=0.2\left(1-\mathrm{T}_{\mathrm{MS} \rightarrow \mathrm{S}}\right)$ & \\
\hline \multicolumn{5}{|c|}{$\mathrm{T}_{\mathrm{for} \rightarrow \mathrm{MB}}=1-\mathrm{T}_{\mathrm{fcr} \rightarrow \mathrm{CO}_{2}}$} \\
\hline \multicolumn{5}{|c|}{$\mathrm{T}_{\mathrm{scr} \rightarrow \mathrm{MB}}=1-\mathrm{T}_{\mathrm{scr} \rightarrow \mathrm{CO}_{2}}$} \\
\hline \multicolumn{5}{|l|}{$\mathrm{T}_{\mathrm{Ir} \rightarrow \mathrm{MS}}=1$} \\
\hline${ }_{M B}=0$ & & & & \\
\hline
\end{tabular}

existing models, it is important to note that this is an attempt to quantitatively and concisely present our current understanding of C and $\mathrm{N}$ cycling. In this process, a large number of processes and parameters are needed to represent even the qualitatively well-known effect of tillage on organic matter turnover rate. It is easy to realize that it is difficult to test each and every coefficient of a model. We are not arguing of course that these parameterizations should not be challenged or open to modifications, but rather that they should be presented and used to allow for further improvements. In this case, the SOC submodel was evaluated using the only longterm data set for SOC in the region, collected at Pendleton, Oregon (Rasmussen and Smiley 1997), with high intensity tillage management. The simulated and observed SOC are shown at two applied $\mathrm{N}$ levels in figures 2 and 3. Perennial grass prairie was the predominant vegetation before the inception of agriculture, and therefore, the stable SOC pool was initialized by apportioning 35\% of the SOC to the stable pool (Gjisman et al. 2002). Model simulations were performed for 55 years before the first SOC measurements in 1931. The initial SOC (unknown) was set to provide SOC content within the range observed at the start of the long-term experiment.

\section{Materials and Methods}

The eastern Washington locations, crop rotations, and tillage sequences simulated in this study are presented in table 3. Lind, St. John, and Pullman are all in the dryland production zone, while Paterson is irrigated.

\section{Figure 2}

CropSyst simulated organic carbon content (lines) at o to $30 \mathrm{~cm}$ depth and 30 to $60 \mathrm{~cm}$ depth of soil near Pendleton, Oregon. Simulated data are superimposed over historic data (symbols) collected at the Columbia Basin Agricultural Research Center, Pendleton, Oregon, between 1931 and 1986. The agronomic system used was dryland winter wheat-summer fallow under conventional tillage. Prior to 1966 , the plots were fertilized with $34 \mathrm{~kg}$ nitrogen $\mathrm{ha}^{-1}$; after 1966, the plots received $90 \mathrm{~kg}$ nitrogen $\mathrm{ha}^{-1}$.

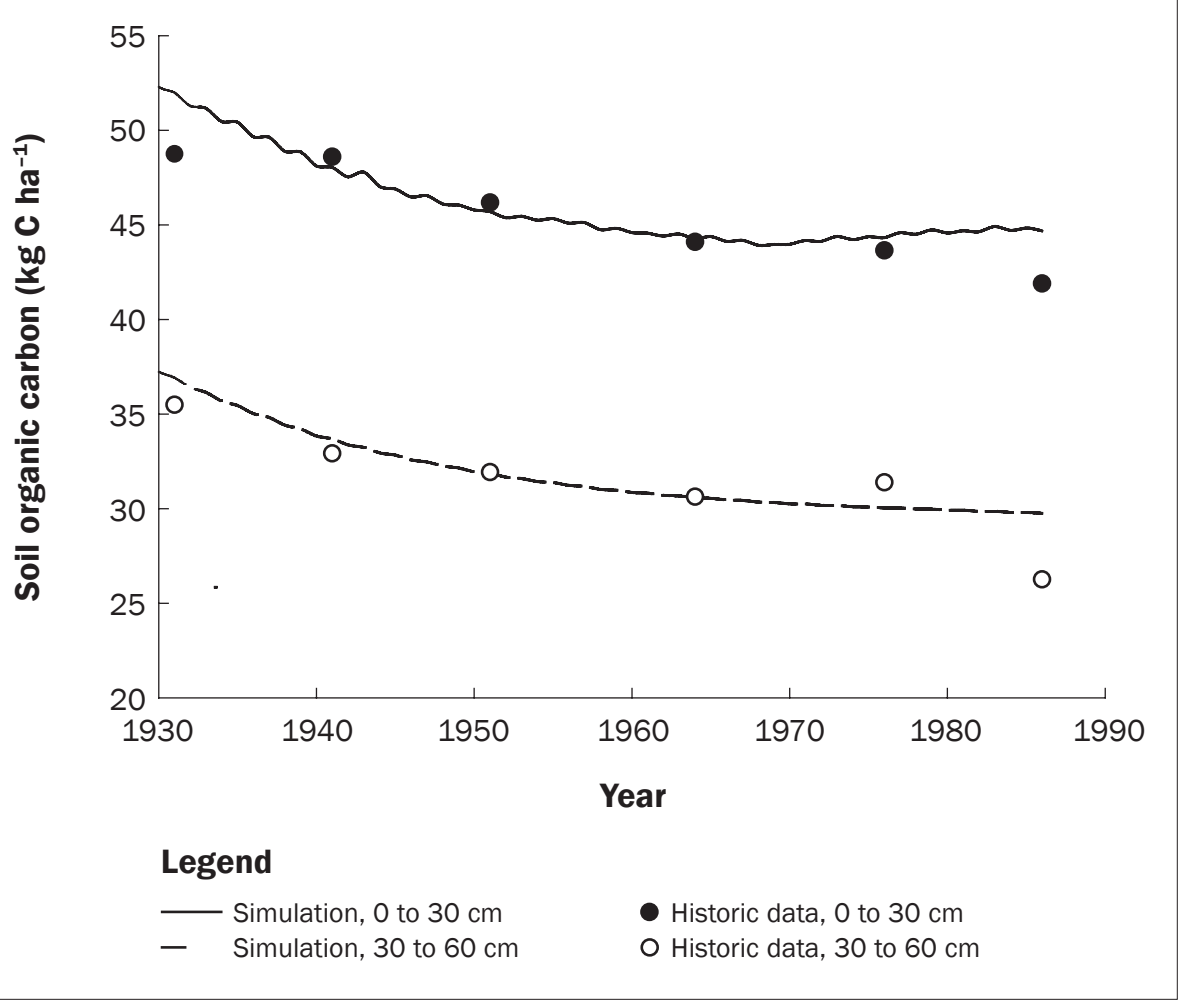




\section{Figure 3}

CropSyst simulated organic carbon content (lines) at o to $30 \mathrm{~cm}$ depth and 30 to $60 \mathrm{~cm}$ depth of soil near Pendleton, Oregon. Simulated data are superimposed over historic data (symbols) collected at the Columbia Basin Agricultural Research Center, Pendleton, Oregon, between 1931 and 1986. The agronomic system used was dryland winter wheat-summer fallow under conventional tillage with no added nitrogen.

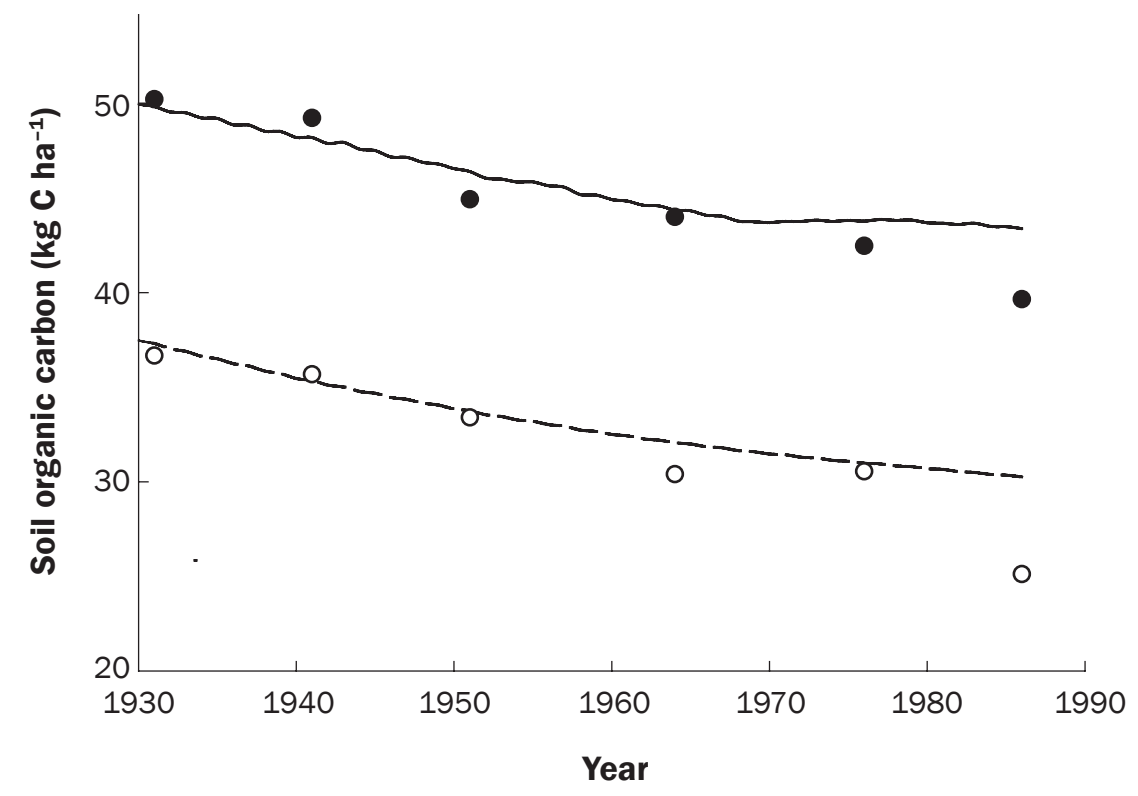

Legend

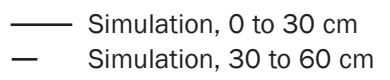

- Historic data, 0 to $30 \mathrm{~cm}$

O Historic data, 30 to $60 \mathrm{~cm}$

\section{Table 3}

Eastern Washington locations, average annual rainfall, tillage intensities (conventional tillage $[\mathrm{CT}]$, reduced tillage [RT], and no-tillage [NT]), crop rotations (winter wheat [WW], summer fallow $[\mathrm{SF}]$, spring barley [SB], spring wheat [SW], spring pea [SP], sweet corn [SC], and potato [P]), and nitrogen $(\mathrm{N})$ fertilization scenarios for the simulations performed with CropSyst.

\begin{tabular}{llllc}
\hline Location & $\begin{array}{l}\text { Rainfall } \\
(\mathbf{m m})\end{array}$ & $\begin{array}{l}\text { Tillage } \\
\text { intensities }\end{array}$ & $\begin{array}{l}\text { Crop } \\
\text { rotation }\end{array}$ & $\begin{array}{l}\text { Average annual } \\
\text { fertilization } \mathbf{( k g ~ N ~ h a - 1})\end{array}$ \\
\hline Lind & 250 & CT, RT & WW-SF & 40 \\
St. John & 435 & CT, NT & WW-SB- SF & 67 \\
Pullman & 550 & CT, RT, NT & WW- SB-SW & 113 \\
Pullman & 550 & CT, RT, NT & WW-SW-SP & 80 \\
Paterson & Irrigated & CT, RT & SC-SC-P & 191 \\
& & & & \\
& & & &
\end{tabular}

Pullman was the only location that included simulations of two crop rotations: one continuous cereal (winter wheat-spring barley (Hordeum vulgare L.)-spring wheat, Pul-b) and the other substituting a legume (spring pea [Pisum sativum L.]) for barley (Pul-p).

Most of the parameters used to define each crop at each location were taken from CropSyst default values, except for those the standard model parameters $\mathrm{F}_{\mathrm{cx}}$ and $\mathrm{F}_{\mathrm{cx}}$ in equation 1 ( 0.5 and 1.5 , respectively), to be referred to as lower oxidation boundary, and with $F_{c x}$ and $F_{s x}$ values of 2 and 6, respectively, thus increasing oxidation rates immediately after heavy tillage from $\sim 1.8$ with the standard parameters to $\sim 4$ with the latter parameterization, referred to as the higher oxidation boundary. The lower boundary provides a similar and somewhat conservative SOC oxidation enhancement compared to field data from two studies (Balesdent et al. 2000; La Scala et al. 2008), while the higher boundary provides a larger enhancement than that reported in the aforementioned studies.

The topography of the dryland cropping region is complex, consisting of rolling hills with varying aspects and slopes, leading to differences in irradiance, soil water content, soil temperature, crop yields, and residue production. Agricultural soils in the region have redistributed and lost $\mathrm{C}$ after the inception of agriculture about 130 years ago, and different locations and positions in the landscape are in different stages of equilibrium with the prevailing wheat-based CT systems. For this reason, the SOC distribution among pools for each crop rotation/location scenario was initialized by running long-term simulations of CT management conditions until a steady state regime was reached. This approach provided a standardized basis to evaluate the conversion of CT to RT or NT for all crop rotation/location scenarios. Conversion to RT or NT was simulated for 30 years in all cases.

The change in SOC $(\Delta \mathrm{SOC})$ resulting from the conversion of CT to NT (or RT) was calculated as

$\Delta \mathrm{SOC}=\mathrm{SOC}_{\mathrm{NT}}-\mathrm{SOC}_{\mathrm{CT}}$,

with $\triangle$ SOC evaluated at $12-$ and 30 -year time spans. Nitrous oxide emissions, a GHG with a large global warming potential, were also simulated considering that they can offset the SOC storage potential of agricultural lands. For consistency, all quantities were expressed in units of $\mathrm{Mg} \mathrm{CO} \mathrm{C} \mathrm{ha}^{-1}$ year $^{-1}\left(\mathrm{CO}_{2} \mathrm{e}\right.$ is $\mathrm{CO}_{2}$ equivalent of SOC or $\mathrm{N}_{2} \mathrm{O}$ ) as used in the assessment of GHG emissions. Nitrous oxide emissions were converted to $\mathrm{CO}_{2}$ equivalents of global warming potential by multiplying $\mathrm{N}_{2} \mathrm{O}$ emissions by 298 (Forster et al. 2007). In addition to CropSyst estimates of $\mathrm{N}_{2} \mathrm{O}$ emissions, to contrast simulation results with an approach widely used as a 


\section{Table 4}

Number of soil-disturbing field operations simulated by CropSyst at various tillage intensities and at several locations in eastern Washington. For the sake of brevity, planters/drills and fertilizer application equipment are not included in the table. Equipment descriptions are consistent with those used by NRCS (2002). Numbers in parentheses refer to the number of operations. The table footnote gives disturbance depths for each operation.

\begin{tabular}{lll}
\hline Location & Tillage & Field operations (number of time used in a rotation) \\
\hline Lnd & CT & Offset heavy disk (1), spike point field cultivator (1), rodweeder (4) \\
Lnd & RT & Sweep plow (1), rodweeder (1) \\
SJ & CT & Moldboard plow (1), straight point chisel (1), sweep field cultivator (2), rodweeder (5) \\
SJ & NT & None \\
Pul-b & CT & Moldboard plow (1), straight point chisel (2), sweep field cultivator (4), spike tooth harrow (1), rodweeder (3) \\
Pul-b & RT & Straight point chisel (3), sweep field cultivator (2), coiled tine harrow (2) \\
Pul-b & NT & None \\
Pul-p & CT & Moldboard plow (1), straight point chisel (2), spike tooth harrow (2), sweep filed cultivator (4), rodweeder (3), cultipacker roller (1) \\
Pul-p & RT & Straight point chisel (2), sweep field cultivator (2), coiled tine harrow (2), cultipacker roller (1) \\
Pul-p & NT & None \\
Pat & CT & Tandem disk (6), straight point chisel (6), bedder hipper hiller (1), furrow diker (1), cultipacker roller (6) \\
Pat & RT & Bedder hipper hiller (1) \\
\hline
\end{tabular}

Notes: Disturbance depths are as follows: Offset heavy disk $(15 \mathrm{~cm})$, spike point field cultivator $(10 \mathrm{~cm})$, rodweeder $(7.5 \mathrm{~cm})$, sweep plow $(7.5 \mathrm{~cm})$, moldboard plow $(20 \mathrm{~cm})$, straight point chisel $(17.5 \mathrm{~cm})$, sweep field cultivator $(3.5 \mathrm{~cm})$, spike tooth harrow $(5 \mathrm{~cm})$, coiled tine harrow $(5 \mathrm{~cm})$, cultipacker roller $(5 \mathrm{~cm})$, tandem disk $(12.5 \mathrm{~cm})$, bedder hipper hiller $(17.5 \mathrm{~cm})$, and furrow diker $(10 \mathrm{~cm})$. Lnd $=$ Lind. SJ = St. John. Pul = Pullman Pat $=$ Paterson. RT = reduced tillage. NT = no-tillage. $-\mathrm{b}$ or $-\mathrm{p}=$ barley or pea in the rotation. See table 3.

generalized first approximation of emissions, we calculated $\mathrm{N}_{2} \mathrm{O}$ emissions as suggested by the United Nations Intergovernmental Panel for Climate Change (IPCC 2006). These IPCC (2006) estimates represent a range of direct $\mathrm{N}_{2} \mathrm{O}$ emissions from managed soils based primarily on the amount of $\mathrm{N}$ applied as fertilizer with adjustments made for the return of residue $\mathrm{N}$ to soil.
Soil erosion by wind and water were estimated for the locations/crop rotations of this study using the Revised Universal Soil Loss Equation, Version 2 (USDA NRCS 2006), and the Wind Erosion Equation (USDA ARS 2004). These simulations were coupled with CropSyst model results to assess the contribution of soil erosional processes to SOC losses.

\section{Results and Discussion}

All locations showed a gain in SOC with decreasing intensity of tillage relative to CT (figure 4). For NT and a 12-year time span, simulated $\Delta \mathrm{SOC}$ were 0.82 to $0.92 \mathrm{Mg} \mathrm{CO}_{2} \mathrm{e}$ $\mathrm{ha}^{-1} \mathrm{y}^{-1}\left(0.37\right.$ to 0.41 th $\left.\mathrm{CO}_{2} \mathrm{e} \mathrm{ac}^{-1} \mathrm{yr}^{-1}\right)$ in the surface $15 \mathrm{~cm}$ (5.9 in) of soil at Pullman (barley in the rotation) and 0.46 to $0.5 \mathrm{Mg} \mathrm{CO}_{2} \mathrm{e}$ $\mathrm{ha}^{-1} \mathrm{y}^{-1}\left(0.21\right.$ to 0.22 tn $\left.\mathrm{CO}_{2} \mathrm{e} \mathrm{ac}^{-1} \mathrm{yr}^{-1}\right)$ at

\section{Figure 4}

Simulated annual change in soil organic carbon (SOC) for (a) the lower oxidation boundary and (b) the upper oxidation boundary obtained by converting from conventional tillage (CT) to either reduced tillage (RT) or no-tillage (NT) in the top $15 \mathrm{~cm}$ of soil for 12-and 30 -year time spans for various tillage intensities and crop rotations at four locations in eastern Washington State. Lnd $=$ Lind, SJ = St. John, Pul = Pullman, Pat $=$ Paterson, and $-b$ or $-\mathrm{p}=$ barley or pea in the rotation (see table 3 ).

(a)

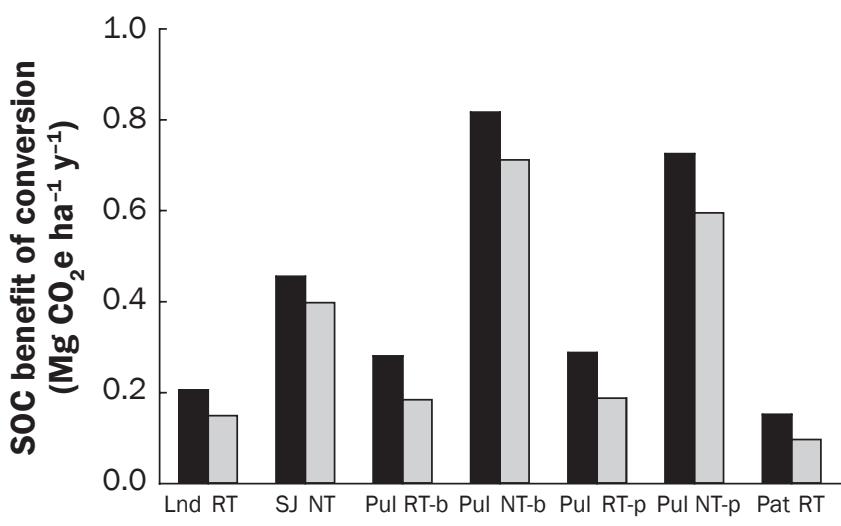

Location-tillage-rotation (b)

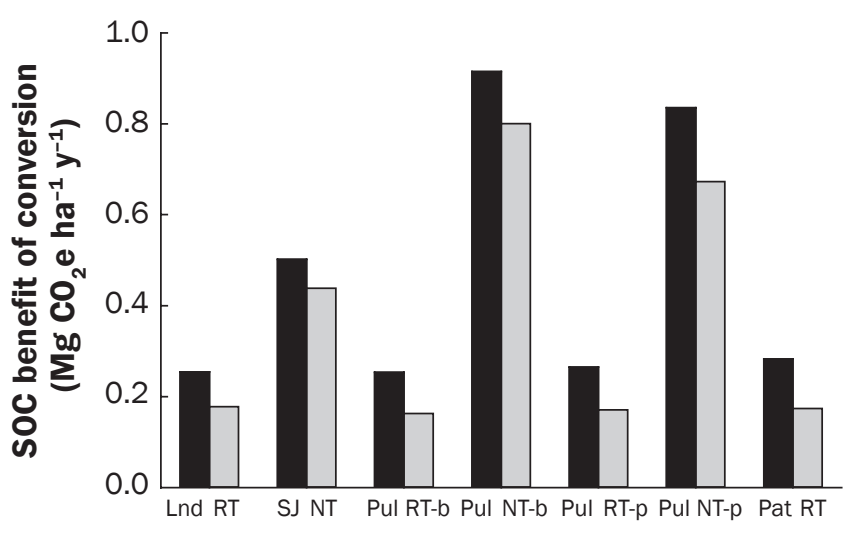

Location-tillage-rotation

Legend

12 year $\square 30$ year 


\section{Figure 5}

Simulated annual change in soil organic carbon (SOC) for (a) the lower oxidation boundary and (b) the upper oxidation boundary obtained by converting from conventional tillage (CT) to either reduced tillage (RT) or no-tillage (NT) in the top $30 \mathrm{~cm}$ of soil for 12-and 30-year time intervals for various tillage intensities and crop rotations at four locations in eastern Washington State. Lnd $=$ Lind, SJ $=$ St. John, Pul = Pullman, Pat $=$ Paterson, and $-b$ or $-p=$ barley or pea in the rotation (see table 3 ).

(a)

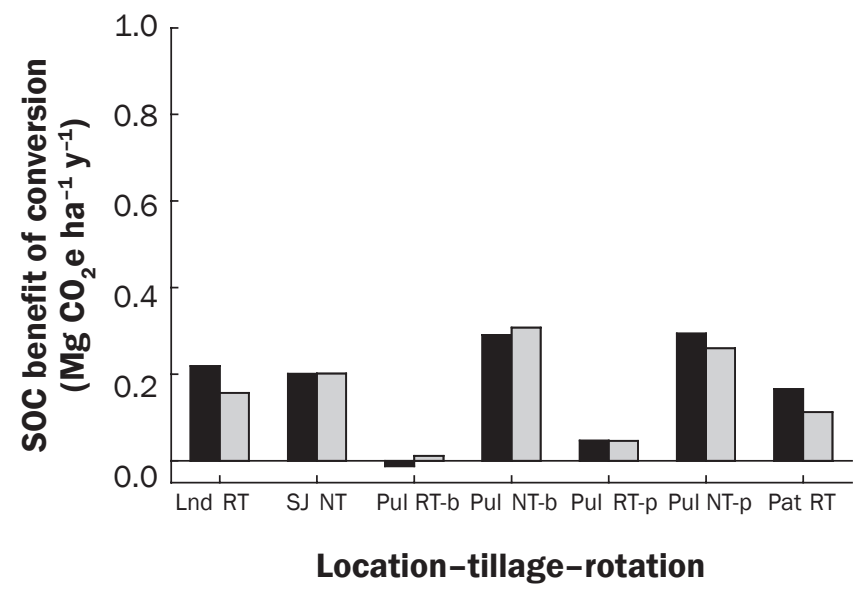

(b)

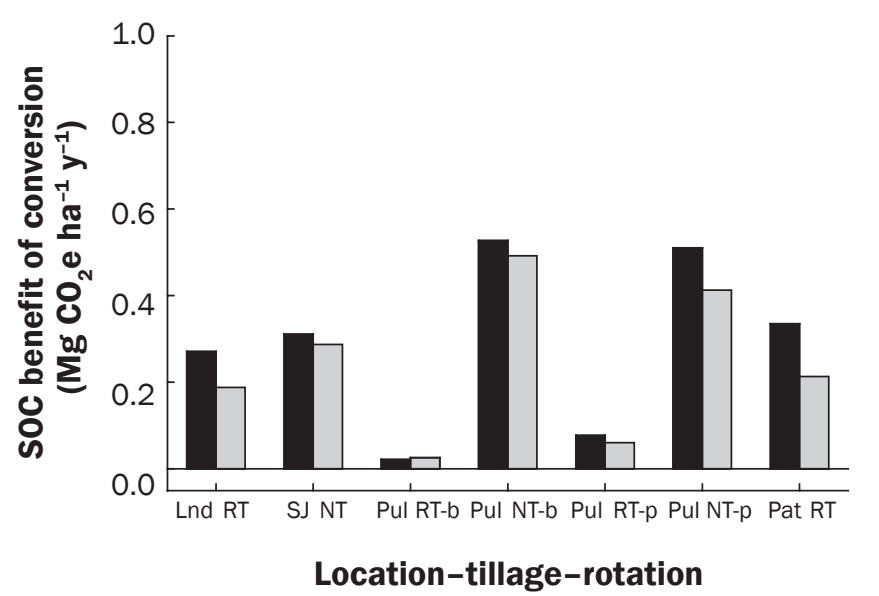

Legend

12 year 230 year

St. John, for the lower and upper oxidation boundary, respectively. For RT at Pullman (barley in the rotation), $\triangle \mathrm{SOC}$ were 0.25 to $0.28 \mathrm{MgCO}_{2} \mathrm{e} \mathrm{ha}^{-1} \mathrm{y}^{-1}$ (0.11 to 0.12 tn $\mathrm{CO}_{2} \mathrm{e}$ $\mathrm{ac}^{-1} \mathrm{yr}^{-1}$ ) for the lower and upper oxidation boundary, respectively, or approximately one third of NT. Net increases in SOC for RT or NT were greater when evaluated over 12 years than when evaluated over 30 years. This trend is explained by the dynamics of SOC after the implementation of less intense tillage. When CT is replaced with either RT or NT, SOC accumulates in the upper $15 \mathrm{~cm}$ of soil, but the rate of change decreases with time as SOC approaches a steady-state with the new tillage management.

Average annual $\triangle \mathrm{SOC}$ in the top $30 \mathrm{~cm}$ (11.8 in) of the soil profile for 12- and 30-year time intervals are presented in figure 5 . The NT scenarios at Pullman and St. John had lower rates of annual $\triangle \mathrm{SOC}$ in the surface $30 \mathrm{~cm}$ compared with the top $15 \mathrm{~cm}$ (5.9 in), indicating that SOC was being lost from the 15 to $30 \mathrm{~cm}$ layer relative to CT. This is to be expected as NT does not incorporate aboveground residues below a soil depth of a few centimeters (any biological redistribution of residues is not accounted for in the model), while CT distributes incorporated residue to deeper depths. For NT and a 12-year time span, $\triangle \mathrm{SOC}$ were 0.29 to $0.53 \mathrm{Mg} \mathrm{CO}_{2} \mathrm{e} \mathrm{ha}^{-1}$ $\mathrm{y}^{-1}$ (0.13 to 0.24 tn $\mathrm{CO}_{2} \mathrm{e} \mathrm{ac}^{-1} \mathrm{yr}-1$; Pullman, barley in the rotation) and 0.2 to $0.31 \mathrm{Mg}$ $\mathrm{CO}_{2} \mathrm{e} \mathrm{ha}^{-1} \mathrm{y}^{-1}$ (0.09 to 0.14 tn $\mathrm{CO}_{2} \mathrm{e} \mathrm{ac}^{-1}$ $\mathrm{yr}^{-1} ;$ St. John), for the lower and upper oxidation boundary, respectively. The SOC storage benefit at Pullman was much less (near zero) for RT compared to NT. With fewer tillage operations at Lind and Paterson (table 4), RT resulted in $\triangle \mathrm{SOC}$ of 0.22 to $0.27 \mathrm{Mg} \mathrm{CO}_{2} \mathrm{e}$ $\mathrm{ha}^{-1} \mathrm{y}^{-1}\left(0.1\right.$ to 0.12 tn $\left.\mathrm{CO}_{2} \mathrm{e} \mathrm{ac}^{-1} \mathrm{yr}^{-1}\right)$ at Lind and 0.17 to $0.33 \mathrm{MgCO}_{2} \mathrm{e} \mathrm{ha}^{-1} \mathrm{y}^{-1}$ (0.08 to 0.15 th $\mathrm{CO}_{2} \mathrm{e} \mathrm{ac}^{-1} \mathrm{yr}^{-1}$ ) at Paterson. When evaluating $\triangle \mathrm{SOC}$ for the entire soil profile, trends were nearly identical to those found for the top $30 \mathrm{~cm}$ (not shown).

Results reported in the literature are mixed concerning the effect of agricultural practices on net SOC sequestration. A global analysis of SOC sequestration rates by West and Post (2002) indicated $\triangle \mathrm{SOC}$ of 1.16 $\mathrm{Mg} \mathrm{CO} \mathrm{e} \mathrm{ha}^{-1} \mathrm{y}^{-1}\left(0.52\right.$ th $\mathrm{CO}_{2} \mathrm{e} \mathrm{ac}^{-1} \mathrm{yr}^{-1}$ ) average for all wheat systems, $0.91 \mathrm{Mg} \mathrm{CO}_{2} \mathrm{e}$ $\mathrm{ha}^{-1} \mathrm{y}^{-1}\left(0.41\right.$ tn $\left.\mathrm{CO}_{2} \mathrm{e} \mathrm{ac}^{-1} \mathrm{yr}^{-1}\right)$ average for continuous wheat systems, and $0.07 \mathrm{Mg}$ $\mathrm{CO}_{2} \mathrm{e} \mathrm{ha}^{-1} \mathrm{y}^{-1}\left(0.03\right.$ tn $\left.\mathrm{CO}_{2} \mathrm{e} \mathrm{ac}^{-1} \mathrm{yr}^{-1}\right)$ average for wheat-fallow systems. Simulations based only on the top $15 \mathrm{~cm}$ (5.9 in) of soil (figure 2) gave values of 0.82 (lower oxidation boundary) and 0.92 (upper oxidation boundary) $\mathrm{Mg} \mathrm{CO}_{2} \mathrm{e} \mathrm{ha}^{-1} \mathrm{y}^{-1}$ (0.37 and 0.41 tn $\mathrm{CO}_{2} \mathrm{e} \mathrm{ac}^{-1} \mathrm{yr}^{-1}$ ) for the most favorable conditions, in reasonable agreement with West and Post (2002) data. However, simu- lated rates of SOC change were substantially lower when the top $30 \mathrm{~cm}$ (11.8 in) of soil were considered (figure 5) and as the amount of rainfall and residue production declined. In Ontario, Canada, zero tillage increased SOC only in the surface layer of soil (Deen and Kataki 2003). In eastern Canada, with moldboard plowing as part of CT management, NT led to increased SOC in the top $20 \mathrm{~cm}$ (7.9 in) relative to CT, but decreased SOC between 20 and $40 \mathrm{~cm}$ (7.9 and 15.7 in) (Angers et al. 1997). In contrast, Huggins et al. (2007) reported 20\% more SOC under NT as compared to CT in the northern US Corn Belt, with 33\% of the increase occurring below the tillage depth. In the Palouse region of eastern Washington, Fuentes et al. (2004) measured $\Delta$ SOC of $0.25 \mathrm{Mg} \mathrm{CO}_{2} \mathrm{e}$ $\mathrm{ha}^{-1} \mathrm{y}^{-1}\left(0.11\right.$ tn $\left.\mathrm{CO}_{2} \mathrm{e} \mathrm{ac}^{-1} \mathrm{yr}^{-1}\right)$ in the top $10 \mathrm{~cm}$ (3.9 in) of soil, while Granatstein et al. (1987), for the same region and cropping system, reported $\triangle \mathrm{SOC}$ of $0.12 \mathrm{Mg} \mathrm{CO}_{2} \mathrm{e} \mathrm{ha}^{-1}$ $\mathrm{y}^{-1}\left(0.05\right.$ tn $\left.\mathrm{CO}_{2} \mathrm{e} \mathrm{ac}^{-1} \mathrm{yr}^{-1}\right)$ over a 10 -year period, with SOC losses in the 10 to $30 \mathrm{~cm}$ layer and accumulation only in the 0 to 5 $\mathrm{cm}$ (0 to 2 in) layer. In reviewing SOC studies throughout the Pacific Northwest, Brown and Huggins (2012) reported that converting CT to NT increased profile SOC at least 0.44 to $0.77 \mathrm{Mg} \mathrm{CO}_{2} \mathrm{e} \mathrm{ha}^{-1} \mathrm{y}^{-1}$ (0.2 to 0.34 tn $\mathrm{CO}_{2} \mathrm{e} \mathrm{ac}^{-1} \mathrm{yr}^{-1}$ ) over 10 to 12 years in $75 \%$ 


\section{Figure 6}

Simulated annual change in carbon ( $C$ ) for ( $a$ and $c$ ) the lower oxidation boundary and ( $b$ and $d$ ) the upper oxidation boundary obtained in the top $30 \mathrm{~cm}$ of soil by converting from conventional tillage (CT) to either reduced tillage (RT) or no-tillage (NT) for both soil organic C (SOC) and residue C at ( $a$ and b) 12-year and ( $c$ and d) 30-year periods for various tillage intensities and crop rotations at four locations in eastern Washington State. Lnd $=$ Lind, $\mathrm{S}$ J = St. John, Pul = Pullman, Pat = Paterson, and $-\mathrm{b}$ or $-\mathrm{p}=$ barley or pea in the rotation (see table 3 ).

(a)

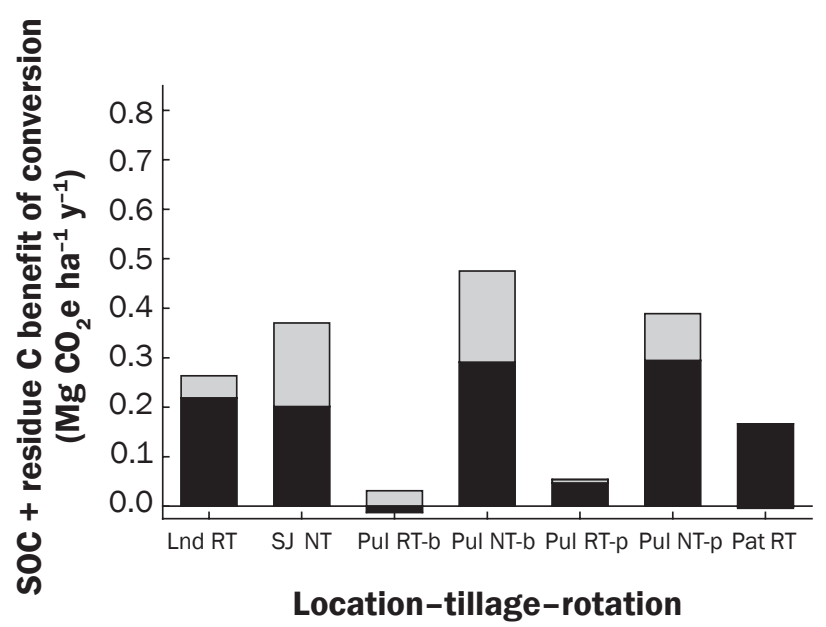

(c)

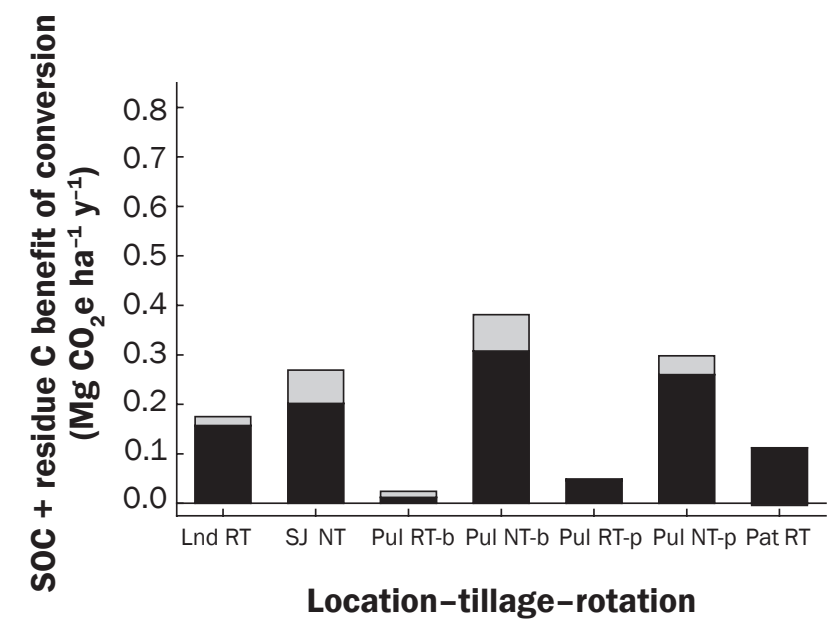

(b)

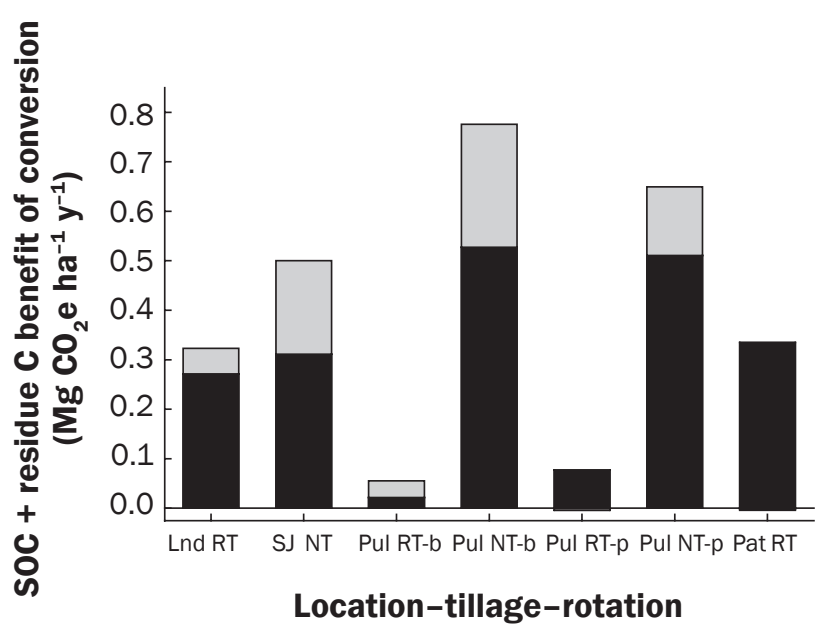

(d)

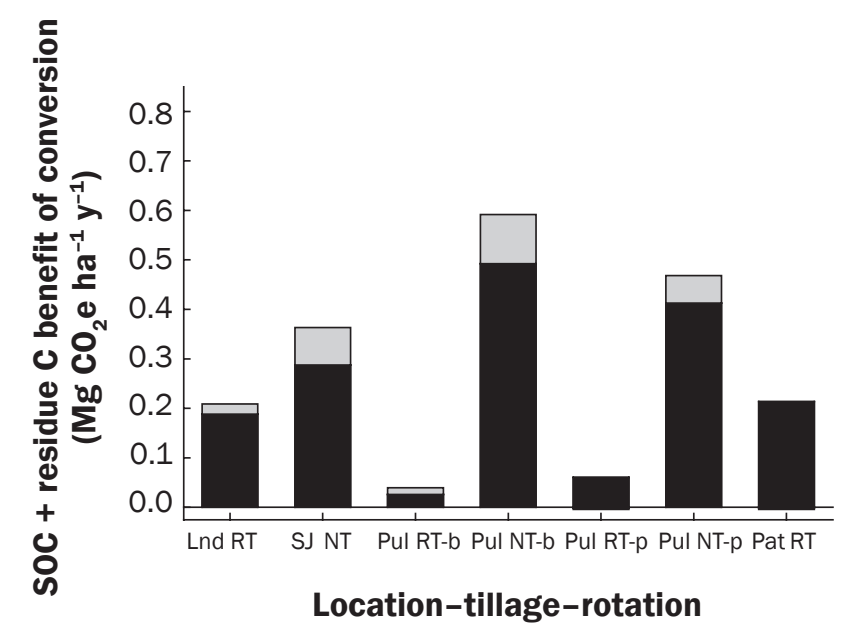

Legend

Soil C

$\square$ Residue C

of studies analyzed, results very similar to the simulated $\triangle$ SOC reported in this study.

An additional major source of $\mathrm{C}$ sequestration that is not often evaluated or measured is that contained in nondecomposed residues derived from both shoots and roots. Residue $\mathrm{C}$ contained within a given field varies considerably from season to season and year to year due to its labile nature. Nevertheless, every cropping system has a potential long-term steady-state amount of residue $\mathrm{C}$ that, if different from another system, can be counted as a contribution toward $\mathrm{C}$ storage. We assumed residue $\mathrm{C}$ (above and below ground) to be the minimum amount that existed $95 \%$ of the time for the last 27 years of the 30-year simulations. This amount of residue $\mathrm{C}$ was divided by 12 for its annual contribution to total $\mathrm{C}$ in the 12 -year analysis and by 30 for the 30 -year analysis, explaining the lower contribution of $\mathrm{C}$ residue for 30-year versus 12-year analyses (figure 6). The $\Delta$ residue (change in residue) $\mathrm{C}$ is the difference of residue $\mathrm{C}$ between NT or RT and CT.
Large contributions of $\Delta$ residue to overall $\triangle \mathrm{SOC}$ were simulated for NT with continuous cereals (NT barley) in Pullman for the 12-year time period where inclusion of steady-state residue $\mathrm{C}$ increased $\mathrm{C}$ sequestration by $62 \%$ and $47 \%$, respectively for the lower and upper oxidation boundary. Even greater percentage increases were simulated for NT in St. John where $\Delta$ residue C increased the overall $\triangle \mathrm{SOC}$ by $85 \%$ and $61 \%$ for the lower and upper oxidation boundary, respectively. In contrast, conversion from 
Table 5

Soil erosion by water and wind estimated using the Revised Universal Soil Loss Equation, Version 2, and Wind Erosion Prediction System, respectively.

\begin{tabular}{|c|c|c|c|c|c|}
\hline $\begin{array}{l}\text { Location/ } \\
\text { tillage }\end{array}$ & $\begin{array}{l}\text { Water erosion } \\
\left(\mathbf{M g ~ h a}^{-1} \mathbf{y}^{-1}\right)\end{array}$ & $\begin{array}{l}\text { Wind erosion } \\
\left(\mathrm{Mg} \mathrm{ha}^{-1} \mathrm{y}^{-1}\right)\end{array}$ & $\begin{array}{l}\text { Total erosion } \\
\left(\mathrm{Mg} \mathrm{ha}^{-1} \mathrm{y}^{-1}\right)\end{array}$ & $\begin{array}{l}\text { SOC removed } \\
\text { with erosion } \\
\left(\mathrm{Mg} \mathrm{SOC} \mathrm{ha}^{-1} \mathrm{y}^{-1}\right)\end{array}$ & $\begin{array}{l}\text { SOC stock in top } \\
0.3 \mathrm{~m} \text { of soil } \\
\left(\mathrm{Mg} \mathrm{SOC}^{-1}\right)\end{array}$ \\
\hline Lnd CT & 1.8 & 23 & 24.8 & 0.126 & 12.3 \\
\hline Lnd RT & 0.9 & 3.7 & 4.6 & 0.023 & 12.3 \\
\hline SJ CT & 15.7 & 0 & 15.7 & 0.121 & 16.7 \\
\hline SJ NT & 0.4 & 0 & 0.4 & 0.003 & 16.7 \\
\hline Pul CT-b & 8.3 & 0 & 8.3 & 0.140 & 52.9 \\
\hline Pul RT-b & 1.1 & 0 & 1.1 & 0.018 & 52.9 \\
\hline Pul NT-b & 0.4 & 0 & 0.4 & 0.007 & 52.9 \\
\hline Pul CT-p & 9.9 & 0 & 9.9 & 0.157 & 50.3 \\
\hline Pul RT-p & 2.2 & 0 & 2.2 & 0.035 & 50.3 \\
\hline Pul NT-p & 0.7 & 0 & 0.7 & 0.011 & 50.3 \\
\hline Pat CT & 3.1 & 124 & 127.1 & 0.469 & 13.3 \\
\hline Pat RT & 0.7 & 96 & 96.7 & 0.357 & 13.3 \\
\hline
\end{tabular}

Notes: SOC $=$ soil organic carbon. Lnd $=$ Lind. SJ $=$ St. John. Pul = Pullman. Pat $=$ Paterson. CT = conventional tillage. RT = reduced tillage. NT = notillage. $-\mathrm{b}$ or $-\mathrm{p}=$ barley or pea in the rotation.

CT to RT sequestered little to no additional $\mathrm{C}$ from $\Delta$ residue, with the possible exception of Lind where several CT fallow tillage operations were replaced with herbicides under RT (table 4). Also in Pullman, conversion to RT with pea in the rotation obtained no benefit from $\Delta$ residue. This occurred as pea plants produce relatively little residue which decays rapidly. This is also the case for potatoes (Solanum tuberosum L.) in Paterson since potato residue decomposes rapidly and because substantial soil disturbance occurs during potato field preparation and harvest.

Soil erosion (water- and wind-induced) is an important process in the study area. Soil erosion by water reduces SOC stocks in eroded sites, with particles and $\mathrm{C}$ transported and deposited at lower positions or leaving fields to enter riparian zones and aquatic systems. Wind erosion removes particles and SOC exposed to wind and distributes them over the landscape. Soil erosion has deleterious effects on soil quality and crop productivity and impacts aquatic systems, leading to sedimentation and eutrophication.

Total soil erosion by wind and water in the region is above tolerable limits for CT management, while it decreases drastically with RT (table 5). Water erosion is more significant in areas with greater precipitation, while wind erosion is more dominant in drier areas. Extremely high wind erosion rates in Paterson, even with RT, result from the low production and short duration of potato residues.
For the purpose of assessing SOC losses as contributions to $\mathrm{CO}_{2}$ emissions, estimates of soil erosion must be interpreted, considering that eroded particles are not lost from the perspective of a wider boundary that encompasses an area larger than that of the contributing eroded sites but are redistributed on the landscape, eventually reaching water bodies and oceans. From this perspective, SOC losses contributing to $\mathrm{CO}_{2}$ emissions occur to the extent that SOC oxidation of removed soil is enhanced compared to the oxidation of the same materials if they remained in situ. This enhancement is a matter of current debate in the literature, with some authors arguing that the overall SOC oxidation is actually reduced by the process of erosion, deposition, and eventual burial of eroded SOC (van Oost et al.2005), with erosion serving as a net sink of $\mathrm{C}$, while others argue against this view and see erosion and deposition serving as a net source of $\mathrm{C}$ to the atmosphere (Lal 2007).

Erosion is spatially dynamic, and soils receive SOC and nutrients from upslope and aeolian deposition (Quinton et al. 2006). In addition, these materials tend to be somewhat enriched in clay content, promoting soil aggregation and physical protection of SOC after deposition. The implication is that the oxidation of deposited SOC may not be much different from the SOC oxidation that would have been obtained if the eroded particles remained in place. Van Hemelryck et al. (2011) reported significantly higher $\mathrm{CO}_{2}$ fluxes from deposited sediments than that from the soil in situ immediately after erosion, but the $\mathrm{CO}_{2}$ pulse was relatively short-lived and consumed a fraction less than $10 \%$ of the deposited SOC.Van Hemelryck et al. (2010) reported that soil redistribution processes contributed additional C emissions of $2 \%$ to $12 \%$ of SOC during a 98 -day period after simulated erosion in laboratory conditions. Their results also suggested that deposition producing a dense stratified layer of sediments that caps the soil surface decreased SOC oxidation in deeper layers.

Another point of contention has been the replacement of lost SOC in eroded sites. Exposure of soil with lower SOC by erosion may restock the soil with $\mathrm{C}$ (Dawson and Smith 2007) if productivity is maintained. Lal (2007) has argued that the replacement of SOC on eroded sites is a slow process and the time lag between removal and replacement must be considered before conclusions about the extent of restocking can be reached. Based on calculations of SOC dynamics within an eroded soil, Billings et al. (2010) estimated that erosion can induce a net $\mathrm{C}$ sink or source depending on management practices and the extent to which SOC oxidation and production characteristics change with erosion.

An important element defining erosion/ deposition processes as net sink or sources of $\mathrm{CO}_{2}$ to the atmosphere is the balance between sediment residence time in transport before burial or entry to aquatic systems (Polyakov and Lal 2008). The longer the residence time, the longer the potential 


\section{Table 6}

Comparison of $\triangle \mathrm{SOC}$ due to tillage (from figure 5) and $\triangle \mathrm{SOC}$ due to removal by erosion assuming an increase of $50 \%$ of the oxidation rate compared to noneroded soil. Calculations are described below.

\begin{tabular}{|c|c|c|c|c|c|c|c|}
\hline $\begin{array}{l}\text { Location/ } \\
\text { tillage }\end{array}$ & $\begin{array}{l}\triangle \mathrm{SOC} * \text { removed } \\
\text { by erosion } \\
\left(\mathrm{Mg} \mathrm{SOC} \mathrm{ha}^{-1} \mathrm{y}^{-1}\right) \\
\end{array}$ & $\begin{array}{l}\triangle S O C \dagger \text { due to } \\
\text { tillage LOB } \\
\left(\mathrm{Mg} \mathrm{CO}_{2} \mathrm{e} \mathrm{ha}^{-1} \mathrm{y}^{-1}\right)\end{array}$ & $\begin{array}{l}\triangle \mathrm{SOC}+\text { due to } \\
\text { tillage UOB } \\
\left(\mathrm{Mg} \mathrm{CO}_{2} \mathrm{e} \mathrm{ha}^{-1} \mathrm{y}^{-1}\right) \\
\end{array}$ & $\begin{array}{l}\triangle S O C \ddagger \text { per unit } \\
\text { SOC LOB } \\
\left(\mathrm{Mg} \mathrm{CO}_{2} \mathrm{e} \mathrm{Mg}^{-1} \mathrm{SOC}\right)\end{array}$ & $\begin{array}{l}\triangle S O C \ddagger \text { per unit } \\
\text { SOC UOB } \\
\left(\mathrm{Mg} \mathrm{CO}_{2} \mathrm{e} \mathrm{Mg}^{-1} \mathrm{SOC}\right)\end{array}$ & $\begin{array}{l}\triangle S O C \S \text { due to } \\
\text { erosion LOB } \\
\left(\mathrm{Mg} \mathrm{CO}_{2} \mathrm{e} \mathrm{ha}^{-1} \mathrm{y}^{-1}\right)\end{array}$ & $\begin{array}{l}\triangle S O C \S \text { due to } \\
\text { erosion UOB } \\
\left(\mathrm{Mg} \mathrm{CO}_{2} \mathrm{e} \mathrm{ha}^{-1} \mathrm{y}^{-1}\right)\end{array}$ \\
\hline & Column 1 & Column 2 & Column 3 & Column 4 & Column 5 & Column 6 & Column 7 \\
\hline Lnd RT & 0.103 & 0.16 & 0.19 & 0.0128 & 0.0151 & 0.00065 & 0.00119 \\
\hline SJ NT & 0.118 & 0.20 & 0.29 & 0.0120 & 0.0171 & 0.00071 & 0.00171 \\
\hline Pul RT-b & 0.121 & 0.01 & 0.03 & 0.0002 & 0.0005 & 0.00001 & 0.00000 \\
\hline Pul NT-b & 0.133 & 0.31 & 0.49 & 0.0058 & 0.0093 & 0.00039 & 0.00143 \\
\hline Pul RT-p & 0.122 & 0.05 & 0.06 & 0.0009 & 0.0011 & 0.00006 & 0.00003 \\
\hline Pul NT-p & 0.146 & 0.26 & 0.41 & 0.0051 & 0.0082 & 0.00037 & 0.00105 \\
\hline Pat RT & 0.112 & 0.11 & 0.21 & 0.0086 & 0.0159 & 0.00048 & 0.00091 \\
\hline
\end{tabular}

Notes: Lnd = Lind. SJ = St. John. Pul = Pullman. Pat = Paterson. CT = conventional tillage. RT = reduced tillage. $\mathrm{NT}=$ no-tillage. $-\mathrm{b}$ or $-\mathrm{p}=$ barley or pea in the rotation. $\mathrm{LOB}=$ lower oxidation boundary. $\mathrm{UOB}=$ upper oxidation boundary.

*Calculated as the difference of CT minus RT or NT erosion rates (table 5).

†From $\triangle \mathrm{SOC}$ values on figure 5 for 30-year time intervals.

¥Calculated dividing $\triangle S O C$ due to tillage (columns 2 and 3) by SOC stock in the top $0.3 \mathrm{~m}$ of soil (table 5).

$\S$ Calculated by multiplying column 1 by column 4 or column 5 .

exposure of eroded materials to conditions enhancing oxidation and the slower the stabilization of deposited SOC by physical protection mechanisms. Deposition of eroded particles in aquatic systems effectively reduces oxidation and stabilizes SOC so that increased sediment delivery ratio (fraction of eroded sediments eventually removed from land and deposited in aquatic systems) will increase SOC sequestration relative to SOC staying in situ. For a watershed in the study region, Fu et al. (2006) estimated that sediment delivery ratios fluctuated depending on proximity to a water stream, with an average of 0.4. McCarty et al. (2009) pointed out that net movement of soil $\mathrm{C}$ into wetter areas of the landscape would tend to stabilize eroded $\mathrm{C}$ by decreasing the potential for oxidation and provided evidence that upland sedimentation of riparian wetland actually stimulated $\mathrm{C}$ sequestration by providing substrate for SOC stabilization.

The SOC dynamics after erosion, deposition, and burial have an impact on how much additional SOC oxidation may occur due to erosion and could contribute to simulated annual $\triangle$ SOC, which do not include erosion (figure 5). Although erosion values are much lower for NT and RT compared to $\mathrm{CT}$ in the study region (table 5), the SOC eroded yearly as a fraction of the SOC stock within the top $0.3 \mathrm{~m}(1 \mathrm{ft})$ of soil depth is small. Thus, even with an unlikely $50 \%$ enhancement of oxidation due to erosion and deposition, and without considering the additional decrease in oxidation resulting from SOC stabilization in aquatic systems, erosion effects would only contribute a modest amount of $\triangle \mathrm{SOC}$ as $\mathrm{CO}_{2}$ emissions attributable as additional benefit of RT or NT (table 6, compare columns 2 and 6 and columns 3 and 7, respectively).

The impact of $\mathrm{N}$ fertilization is also of interest when considering the potential for climate change mitigation derived from improved agricultural practices. Simulated $\mathrm{N}_{2} \mathrm{O}$ emissions showed relatively small responses to tillage intensity and to the degree of enhanced soil oxidation induced by tillage (figure 7 ). Simulated $\mathrm{N}_{2} \mathrm{O}$ emissions in dryland were lowest in Lind, which was the driest location and where fertilizer was applied only every other year. The next lowest emission was simulated in Paterson under irrigation, which was surprising given the high fertilizer inputs and irrigation but consistent with local measurements (HaileMariam et al. 2008). In the Haile-Mariam et al. (2008) study, crops were fertilized with N by fertigation through the pivots, applying 25 to $40 \mathrm{~kg} \mathrm{~N} \mathrm{ha}^{-1}$ (22.3 to $35.7 \mathrm{lb} \mathrm{N} \mathrm{ac}{ }^{-1}$ ) weekly over the growing season, thereby limiting excess $\mathrm{N}$ in the system. Paterson also has soils with $>90 \%$ sand, which, combined with a high $\mathrm{N}$ uptake by the crops grown there, may have restricted the anaerobic conditions and high $\mathrm{NO}_{3}$-availability required for denitrification. In Pullman, when pea was in the rotation, simulated $\mathrm{N}_{2} \mathrm{O}$ emissions were lower than when barley was in the rotation. In Pullman and Paterson, simulated $\mathrm{N}_{2} \mathrm{O}$ emissions tended to decrease with decreasing tillage intensity (figure 7). These lower simulated emissions are explained by a combination of lower soil temperatures under residue and less $\mathrm{N}$ availability in the top soil due to immobilization.

The IPCC estimates of $\mathrm{N}_{2} \mathrm{O}$ emissions are also presented in figure 7 where both the midpoint of the IPCC range of values along with the minimum value in the range are represented. The IPCC estimates are not only high relative to simulated estimates of $\mathrm{N}_{2} \mathrm{O}$ emissions from the modeled agricultural systems, but they are also high relative to locally collected field data. The lower boundary of the IPCC range corresponds reasonably well, however, to the simulation estimates (figure 7). For Paterson, the IPCC midrange-estimated $\mathrm{N}_{2} \mathrm{O}$ emission of 1.26 $\mathrm{Mg} \mathrm{CO}$ e ha $\mathrm{ha}^{-1} \mathrm{y}^{-1}\left(0.56\right.$ th $\mathrm{CO}_{2} \mathrm{e} \mathrm{ac}^{-1} \mathrm{yr}^{-1}$; figure 7$)^{2}$ is 4.5 times the value calculated from the data of Haile-Mariam et al (2008) for a similar rotation and tillage modeled herein. In contrast, the CropSyst estimate of $\mathrm{N}_{2} \mathrm{O}$ emissions for Paterson, averaged over both CT and RT, was $0.27 \mathrm{Mg} \mathrm{CO}_{2} \mathrm{e} \mathrm{ha}^{-1} \mathrm{y}^{-1}$ (0.12 tn $\mathrm{CO}_{2} \mathrm{e} \mathrm{ac}^{-1} \mathrm{yr}^{-1}$ ), almost identical to that reported by Haile-Mariam et al. (2008) based on field measurements, although their measurement only included the period from May to September (when fertilization and irrigations were applied). Haile-Mariam et al. (2008) pointed out that the bulk of fertilization applied during that study was $\mathrm{NH}_{4}-\mathrm{N}$ from urea-ammonium nitrate (UAN) and that it was likely that a significant fraction of the $\mathrm{N}_{2} \mathrm{O}$ emission came from nitrifica- 


\section{Figure 7}

Annual nitrous oxide $\left(\mathrm{N}_{2} \mathrm{O}\right)$ emissions, averaged over 30 years, either simulated by CropSyst or calculated according to the Intergovernmental Panel for Climate Change (IPCC) guidelines (2006), for various tillage intensities and crop rotations at four locations in eastern Washington State. Simulated data presented for either lower oxidation boundary in response to tillage or upper oxidation boundary. Lnd = Lind, $\mathrm{S}$ J $=$ St. John, Pul = Pullman, Pat = Paterson, CT = conventional tillage, $\mathrm{RT}=$ reduced tillage, $\mathrm{NT}=$ no-tillage, and $-\mathrm{b}$ or $-\mathrm{p}=$ barley or pea in the rotation (see table 3 ). Crop yields for the IPCC calculations came from the lower oxidation boundary CropSyst scenarios.

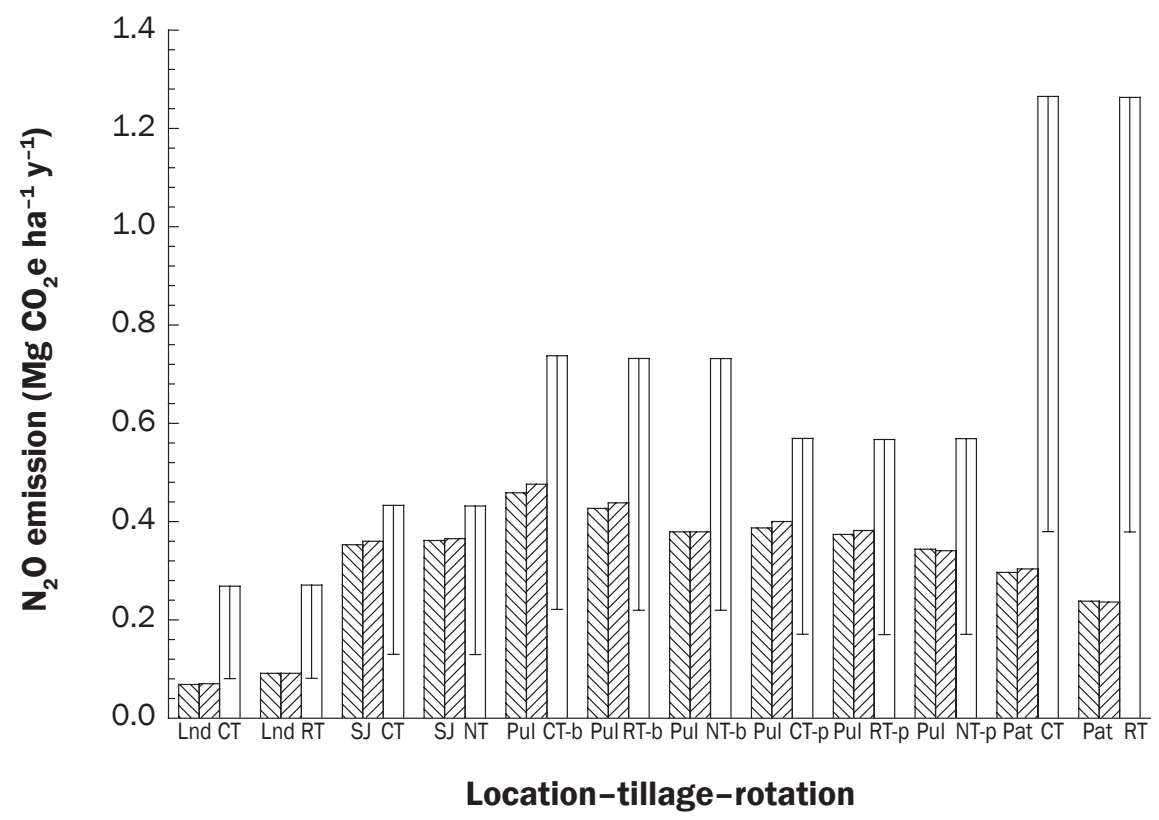

Legend

MIV Lower oxidation boundary $\quad Z A$ Upper oxidation boundary $\square$ IPCC with low range

tion rather than denitrification. In this case, small, frequent, center-pivot water applications combined with the site's sandy soils were unlikely to result in significant anaerobic conditions. The simulations showed that between $50 \%$ and $60 \%$ of yearly $\mathrm{N}_{2} \mathrm{O}$ emissions were associated with nitrification in this location.

In a previous study near Pullman, measured $\mathrm{N}_{2} \mathrm{O}$ emission over a 5 -week period (starting May 21, 1976) on a fallow soil with a high rate of $\mathrm{N}$ fertilization $\left(220 \mathrm{~kg} \mathrm{~N} \mathrm{ha}^{-1}\right.$ [196.3 lb $\left.\mathrm{N} \mathrm{ac}{ }^{-1}\right]$ as anhydrous ammonia $\left[\mathrm{NH}_{3}\right]$ ), was about $0.1 \%$ of applied $\mathrm{N}$ via nitrification (Cochran et al 1981). An unfertilized control produced an average daily emission of $\sim 0.9 \mathrm{~g} \mathrm{~N} \mathrm{ha}^{-1} \mathrm{~d}^{-1}\left(0.013 \mathrm{oz} \mathrm{ac}^{-1}\right.$ day $^{-1}$; with a maximum of $2 \mathrm{~g} \mathrm{~N} \mathrm{ha}^{-1} \mathrm{~d}^{-1}\left[0.029 \mathrm{oz} \mathrm{ac}^{-1}\right.$ day $\left.\left.^{-1}\right]\right)$. Data collected on a NT spring wheat field by Huggins and coworkers (USDA, Pullman, Washington, personal communication) at Pullman, following application of $107 \mathrm{~kg} \mathrm{~N} \mathrm{ha}^{-1}\left(95.5 \mathrm{lb} \mathrm{N} \mathrm{ac}^{-1}\right)$ of UAN 32 (75\% ammoniacal $\mathrm{N})$ three days earlier, and receiving enough water to fill the top
$20 \mathrm{~cm}$ (7.9 in) of soil to $80 \%$ water filled porosity just before measurement, showed an average $\mathrm{N}_{2} \mathrm{O}$ emission of $56 \mathrm{~g} \mathrm{~N} \mathrm{ha}^{-1} \mathrm{~d}^{-1}$ $\left(0.78 \mathrm{oz} \mathrm{ac}^{-1} \mathrm{day}^{-1}\right)$. Assuming the maximum emission rate of $2 \mathrm{~g} \mathrm{~N} \mathrm{ha}^{-1}\left(2.9 \mathrm{~g} \mathrm{~N} \mathrm{ha}^{-1} \mathrm{~d}^{-1}\right.$ [0.041 oz ac ${ }^{-1}$ day $\left.^{-1}\right]$ at optimal temperature) of the unfertilized treatment from Cochran et al. (1981) as daily $\mathrm{N}_{2} \mathrm{O}$ fluxes during dry days, and the emission rate for the watered treatment from Huggins and coworkers as an estimate of $\mathrm{N}_{2} \mathrm{O}$ emission for rainy days (122 $\mathrm{g} \mathrm{N} \mathrm{ha}^{-1} \mathrm{~d}^{-1}\left[1.74 \mathrm{oz} \mathrm{ac}^{-1}\right.$ day $\left.^{-1}\right]$ at optimal temperature and occurring in each day with a rainfall amount exceeding $8 \mathrm{~mm}$ [0.3 in]), a simplified high-end $\mathrm{N}_{2} \mathrm{O}$ emission estimation of $0.52 \mathrm{MgCO}_{2} \mathrm{e} \mathrm{ha}^{-1} \mathrm{y}^{-1}(0.23 \mathrm{tn}$ $\mathrm{CO}_{2} \mathrm{e} \mathrm{ac}^{-1} \mathrm{yr}^{-1}$ ) for the year 1976 at Pullman was obtained. Simulated annual $\mathrm{N}_{2} \mathrm{O}$ emission averaged over all Pullman scenarios was $0.40 \mathrm{Mg} \mathrm{CO} \mathrm{e} \mathrm{ha}^{-1} \mathrm{y}^{-1}\left(0.18\right.$ tn $\mathrm{CO}_{2} \mathrm{e} \mathrm{ac}^{-1}$ $\mathrm{yr}^{-1} ; 55 \%$ to $58 \%$ of the yearly $\mathrm{N}_{2} \mathrm{O}$ emission derived from nitrification). The midrange IPCC estimate for Pullman was somewhat higher, at $0.65 \mathrm{Mg} \mathrm{CO}_{2} \mathrm{e} \mathrm{ha}^{-1} \mathrm{y}^{-1}$ (0.29 tn $\left.\mathrm{CO}_{2} \mathrm{e} \mathrm{ac}^{-1} \mathrm{yr}^{-1}\right)$.
The $\mathrm{N}_{2} \mathrm{O}$ emissions shown in figure 7 are large enough to offset gains in SOC storage. However, given that the simulated $\mathrm{N}_{2} \mathrm{O}$ emissions do not differ much as a function of tillage intensity, the benefit of switching from CT to NT discussed herein is still valid.

\section{Summary and Conclusions}

The potential for SOC sequestration in the top $30 \mathrm{~cm}$ (11.8 in) of soil after switching from CT to NT $(\Delta \mathrm{SOC})$ was 0.29 to 0.53 $\mathrm{MgCO}_{2} \mathrm{e} \mathrm{ha}^{-1} \mathrm{y}^{-1}$ (0.13 to 0.24 tn $\mathrm{CO}_{2} \mathrm{e} \mathrm{ac}^{-1}$ $\mathrm{yr}^{-1}$ ) for a winter wheat/spring barley/spring wheat rotation at Pullman $(550 \mathrm{~mm}$ [22 in] of annual precipitation), declining to 0.2 to 0.31 $\mathrm{MgCO}_{2} \mathrm{e} \mathrm{ha}^{-1} \mathrm{y}^{-1}$ (0.09 to 0.14 tn $\mathrm{CO}_{2} \mathrm{e} \mathrm{ac}^{-1}$ $\mathrm{yr}^{-1}$ ) for a winter wheat/spring barley/summer fallow rotation at St. John (435 mm [17 in]). A rotation substituting peas for barley at Pullman resulted in slightly lower $\mathrm{C}$ gains. At Lind (winter wheat/summer fallow rotation, $250 \mathrm{~mm}$ [10 in] of annual precipitation), where RT management is the typical alternative to $\mathrm{CT}$, SOC storage gain was lowest (0.22 to $0.27 \mathrm{Mg} \mathrm{CO}_{2} \mathrm{e} \mathrm{ha}^{-1} \mathrm{y}^{-1}$ [0.1 to 0.12 tn $\left.\mathrm{CO}_{2} \mathrm{e} \mathrm{ac}^{-1} \mathrm{yr}^{-1}\right]$ ) due to low residue production and some soil disturbance. Overall, RT was less effective than NT in obtaining SOC gains. Under irrigation on sandy soils at Paterson (sweet corn-sweet corn-potato rotation), 0.17 to $0.33 \mathrm{Mg} \mathrm{CO} \mathrm{e} \mathrm{ha}^{-1} \mathrm{y}^{-1}$ (0.8 to 0.15 tn $\mathrm{CO}_{2} \mathrm{e} \mathrm{ac}^{-1} \mathrm{yr}^{-1}$ ) of SOC gain was possible after switching from CT to RT due to larger residue production. The yearly rates of SOC gain after conversion to NT or RT from CT were higher when evaluated for a 12-year than a 30-year time span, although this is clearly a matter of the time frame selected.

Evaluating $\triangle \mathrm{SOC}$ based on the top 0 to $15 \mathrm{~cm}$ (0 to $5.9 \mathrm{in})$ soil depth or less could provide an undue advantage when evaluating potential $\mathrm{C}$ sequestration benefits of $\mathrm{NT}$ management. Comparisons should be made at least on the basis of the depth of surface residue redistributed by tillage when comparing CT to NT, or preferably by evaluating the entire soil profile. Including steady-state residue $\mathrm{C}$ differences, however, could substantially increase estimated $\mathrm{C}$ sequestration due to conversion from CT and RT to NT.

Soil erosion rates under CT in the study region are high, posing deleterious effects on soil quality, productivity, and aquatic systems. However, an analysis that includes deposition, burial, and sedimentation on terrestrial and aquatic systems of eroded SOC indicates that 
the substantial erosion reduction obtained with RT and NT may result only in minor additional SOC oxidation as compared to CT. Emissions of $\mathrm{N}_{2} \mathrm{O}$ in the cropping systems evaluated were sufficiently high to offset gains in SOC, although they were not a factor when comparing the net benefit of CT to NT conversion since these emissions were similar in the two systems. Reducing tillage intensity can result in $\mathrm{C}$ sequestration, but mitigation of GHG is limited unless it is coupled with $\mathrm{N}$ fertilizer management to also reduce $\mathrm{N}_{2} \mathrm{O}$ emission.

\section{Acknowledgements}

This research was supported in part by the Paul G. Allen Family Foundation and Award \#201-68002-30191 from the USDA National Institute for Food and Agriculture.

\section{References}

Allmaras, R.R., H.H. Schomberg, C.L. Douglas, Jr., and T.H. Dao. 2000. Soil organic carbon sequestration potential of adopting conservation tillage in US croplands. Journal of Soil and Water Conservation 55(3):365-373.

Angers, D.A., M.A. Bolinder, M.R. Carter, E.G. Gregorich, C.F. Drury, B.C. Liang, R.P.Voroney, R.R. Simard, R.G. Donald, R.P. Beyaert, and J. Martel. 1997. Impact of tillage practices on organic carbon and nitrogen storage in cool, humid soils of eastern Canada. Soil Tillage Research 41:191-201.

Baker, J.M, T.E. Ochsner, R.T.Venterea, and T.J. Griffis. 2007. Tillage and soil carbon sequestration-What do we really know? Agriculture, Ecosystems and Environment 118:1-5.

Balesdent, J., C. Chenu, and M. Balabane. 2000. Relationship of soil organic matter dynamics to physical protection and tillage. Soil \& Tillage Research 53:215-230.

Billings, S.A., R.W. Buddemeier, D. deB. Richter, K.Van Oost, and G. Bohling. 2010. A simple method for estimating the influence of eroding soil profiles on atmospheric $\mathrm{CO}_{2}$. Global Biogeochemical Cycles 24, GB2001.

Brown, T.T., and D.R. Huggins. 2012. Dryland agriculture's impact on soil carbon in the Pacific Northwest. Journal of Soil and Water Conservation 67(5):406-415, doi:10.2489/jswc.67.5.406.

Bruce, J.P., M. Frome, E. Haites, H. Janzen, R. Lal, and K. Paustian. 1999. Carbon sequestration in soils. Journal of Soil and Water Conservation 54(1):382-389.

Carvalho Leite, L.F., E. Sa Mendonca, P.L. Oliveira de Almeida Machado, E.I. Fernandes Filho, and J.C. Lima Neves. 2004. Simulating trends in soil organic carbon of an Acrisol under no-tillage and disc-plow systems using the Century model. Geoderma 120:283-295.

Castellvi, F, and C.O. Stöckle. 2001. Comparing the performance of WGEN and ClimGen in the generation of temperature and solar radiation. Transactions of the American Society of Agricultural Engineers 44:1683-1687.

Chatskikh, D., and J.E. Olesen. 2007. Soil tillage enhanced $\mathrm{CO}_{2}$ and $\mathrm{N}_{2} \mathrm{O}$ emissions from loamy sand soil under spring barley. Soil and Tillage Research 97:5-18.

Cochran,V. L, L.F. Elliott, and R.I. Papendick. 1981. Nitrous oxide emissions from a fallow field fertilized with anhydrous ammonia. Soil Science Society of America Journal 45:307-310.

Collins, H.P., E.T. Elliott, K. Paustian, L.G. Bundy, W.A. Dick, D.R. Huggins, A.J.M. Smucker, and E.A. Paul. 2000. Soil carbon pools and fluxes in long-term corn belt agroecosystems. Soil Biology \& Biochemistry 32:157-168.

Conant, R.T., M. Easter, K. Paustian, A. Swan, and S. Williams. 2007. Impacts of periodic tillage on soil C stocks: A synthesis. Soil \& Tillage Research 95:1-10.

Dawson, J.J.C., and P. Smith. 2007. Carbon losses from soil and its consequences for land-use management. Science of the Total Environment 382:165-190.

Deen, W., and P.K. Kataki. 2003. Carbon sequestration in a long-term conventional versus conservation tillage experiment. Soil \& Tillage Research 74:143-150.

Del Grosso, S.J., W.J. Parton, A.R. Mosier, D.S. Ojima, A.E. Kulmala, and S. Phongpan. 2000. General model for $\mathrm{N}_{2} \mathrm{O}$ and $\mathrm{N}_{2}$ gas emission from soils due to nitrification. Global Biogeochemical Cycles 14:1045-1060.

Forster, P., V. Ramaswamy, P. Artaxo, T. Berntsen, R. Betts, D.W. Fahey, J. Haywood, J. Lean, D.C. Lowe, G. Myhre, J. Nganga, R. Prinn, G. Raga, M. Schulz, and R. Van Dorland. 2007. 2007: Changes in Atmospheric Constituents and in Radiative Forcing. In Climate Change 2007: The Physical Science Basis, eds. S. Solomon, D. Qin, M. Manning, Z. Chen, M. Marquis, K.B. Averyt, M. Tignor, and H.L. Miller. Contribution of Working Group I to the Fourth Assessment Report of the Intergovernmental Panel on Climate Change. Cambridge and New York: Cambridge University Press. Fu, G., S. Chen, and D.K. McCool. 2006. Modeling the impacts of no-till practice on soil erosion and sediment yield with RUSLE, SEED, and ArcView GIS. Soil \& Tillage Research 85:38-49.

Fuentes, J.P., M. Flury, and D.F. Bezdicek. 2004. Hydraulic properties in a silt loam soil under natural prairie, conventional till, and no-till. Soil Science Society of America Journal 68:1679-1688.

Gijsman, A., G. Hoogenboom, W.J. Parton, and P.C. Kerridge. 2002. Modifying DSSAT crop models for low-input agricultural systems using a soil organic matter-residue module from Century. Agronomy Journal 94:462-474.

Granatstein, D.M., D.F. Bezdicek, V.L. Cochran, L.F. Elliott, and J. Hammel. 1987. Long-term tillage and rotation effects on soil microbial biomass, carbon, and nitrogen. Biology and Fertility of Soils 5:265-270.

Haile-Mariam, S., H.P. Collins, and S.S. Higgins. 2008. Greenhouse gas fluxes from an irrigated sweet corn
(Zea mays L.) - potato (Solanum tuberosum L.) rotation. Journal of Environmental Quality 37:759-711.

Huggins, D.R., R.R. Allmaras, C.E. Clapp, J.A. Lamb, and G.W. Randall. 2007. Corn-soybean sequence and tillage effects on soil carbon dynamics and storage. Soil Science Society of America Journal 71:145-154.

Huggins, D.R., G.A.Buyanovsky, G.H. Wagner, J.R. Brown, R.G. Darmody, T.R. Peck, G.W. Lesoing, M.B. Vanotti, and L.G. Bundy. 1998. Soil organic C in the tall-grass prairie-derived region of the Corn Belt: Effects of long-term crop management. Soil \& Tillage Research 47:219-234.

IPCC (Intergovernmental Panel on Climate Change). 2006. 2006 IPCC Guidelines for National Greenhouse Gas Inventories Volume 4 Agriculture, Forestry and Other Land Use. Prepared by the National Greenhouse Gas Inventories Programme, eds. H.S. Eggleston, L. Buendia, K. Miwa, T. Ngara, and K. Tanabe. Hayama, Kanagawa, Japan: Institute for Global Environmental Strategies.

Kemanian, A.R., S. Julich, V.S. Manoranjan, and J.R. Arnold, 2011. Integrating carbon, nitrogen, and phosphorus cycling in the watershed model SWAT: Theory and model testing. Ecological Modelling 222:1913-1921.

Kemanian, A.R., and C.O. Stöckle. 2010. C-Farm: A simple model to evaluate the carbon balance of soil profiles. European Journal of Agronomy 32:22-29.

Kroeze, C.,A.R. Mosier, and L. Bouwman.1999. Closing the global $\mathrm{N}_{2} \mathrm{O}$ budget: A retrospective analysis 1500-1994. Global Biogeochemical Cycles 13:1-8.

Krull, E.S., J.A. Baldock, and J.O. Skjemstad. 2003. Importance of mechanisms and processes of the stabilisation of soil organic matter for modeling carbon turnover. Functional Plant Biology 30:207-222.

Lal, R. 2007. Carbon management in agricultural soils. Mitigation and Adaptation Strategies for Global Change 12:303-322.

Lal, R., R.F. Follett, J. Kimble, and C.V. Cole. 1999. Managing US cropland to sequester carbon in soil. Journal of Soil and Water Conservation 54(1):374-381.

La Scala, N. Jr., A. Lopes, K. Spokas, D. Bolonhezi, D.W. Archer, and D.C. Reicosky. 2008. Short-term temporal changes of soil carbon losses after tillage described by a first-order decay model. Soil \& Tillage Research 99:108-118.

Maag, M., and F.P.Vinther. 1996. Nitrous oxide emission by nitrification and denitrification in different soil types and at different soil moisture contents and temperatures. Applied Soil Ecology 4:5-14.

McCarty, G., Y. Pachepsky, and J. Ritchie. 2009. Impact of sedimentation on wetland carbon sequestration in an agricultural watershed. Journal of Environmental Quality 38:804-813.

McGill W.B., H.W. Hunt, G.G. Wodmansee, and J.O. Reuss. 1981. PHOENIX, a model of the dynamics of carbon and nitrogen in grassland soils. In Terrestrial Nitrogen Cycles: Processes, Ecosystem Strategies, and 
Management Impacts, eds. F.E. Clark and T. Rosswall. Ecological Bulletin 33:49-115.

Meier, E.A., P.J. Thorburn, and M.E. Probert. 2006 Occurrence and simulation of nitrification in two contrasting sugarcane soils from the Australian wet tropics. Soil Research 44:1-9.

Molina, J.A.E., and P. Smith. 1998. Modeling carbon and nitrogen processes in soils. Advancements in Agronomy 62:253-298.

Monzon, J.P., V.O. Sadras, and F.H. Andrade. 2006. Fallow soil evaporation and water storage as affected by stubble in sub-humid (Argentina) and semi-arid (Australia) environments. Field Crops Research 98:83-90.

Pala, M., C.O. Stöckle, and H.C. Harris. 1996. Simulation of durum wheat (triticum durum) growth under differential water and nitrogen regimes in a mediterranean type of environment using CropSyst. Agricultural Systems 51:147-163.

Pannkuk, C.D., C.O. Stöckle, and R.I. Papendick. 1998. Validation of CropSyst for winter and spring wheat under different tillage and residue management practices in a wheat-fallow region. Agricultural Systems 57:121-134.

Parton, W.J., A.R. Mosier, D.S. Ojima, D.W. Valentine, D.S. Schimel, K. Weier, and A.E. Kulmala. 1996. Generalized model for $\mathrm{N}_{2}$ and $\mathrm{N}_{2} \mathrm{O}$ production from nitrification and denitrification. Global Biogeochemical Cycles 10:401-412.

Parton, W.J., D.S. Ojima, C.V. Cole, and D.S. Schimel. 1994. A general model for soil organic matter dynamics: Sensitivity to litter chemistry, texture and management. In Quantitative modeling of soil forming processes. Special Publication 39. Madison, WI: Soil Science Society of America.

Parton, W.J., and P.E. Rasmussen. 1994. Long-term effects of crop management in wheat-fallow: II. CENTURY model simulations. Soil Science Society of America Journal 58:530-536

Parton, W.J., J.W.B. Stewart, and C.V. Cole. 1988. Dynamics of C, N, P and S in grassland soils: A model. Biogeochemistry 5:109-131.

Peralta,J.M., and C.O.Stöckle. 2002. Nitrate from an irrigated crop rotation at the Pasco-Quincy area (Washington, USA) available for groundwater contamination: A longterm simulation study. Agriculture, Ecosystems and Environment 88:23-24.

Polyakov,V.O., and R. Lal. 2008. Soil organic matter and $\mathrm{CO}_{2}$ emission as affected by water erosion on filed runoff plots. Geoderma 143:216-222.

Powlson, D.S., P. Smith, and J.U. Smith. 1996. Evaluation of soil organic matter models using existing long-term datasets. NATO ASI Series, Vol. I:38.

Quinton, J.N., J.A. Catt, G.A. Wood, and J. Steer. 2006. Soil carbon losses by water erosion: Experimentation and modeling at field and national scales in the UK. Agriculture, Ecosystems \& Environment 112:87-102.
Rasmussen, P.E., S.L. Albrecht, and R.W. Smiley. 1998. Soil $\mathrm{C}$ and $\mathrm{N}$ changes under tillage and cropping systems in semi-arid Pacific Northwest agriculture. Soil \& Tillage Research 47:197-205.

Rasmussen, P.E., and R.W. Smiley. 1997. Soil carbon and nitrogen change in long-term agricultural experiments at Pendleton, Oregon. In Soil Organic Matter in Temperate Agroecosystems: Long-Term Experiments in North America, eds. E.A. Paul, K. Paustian, E.T. Elliott, and C.V. Cole, 353-360. Boca Raton: CRC Press.

Shaffer, M.J, L. Ma, and S. Hansen. 2001. Modeling Carbon and Nitrogen Dynamics for Soil Management. Boca Raton, FL: CRC Press.

Six, J., H. Bossuyt, S. Degryze, and K. Denef. 2004a. A history of research on the link between (micro)aggregates, soil biota, and soil organic matter dynamics. Soil \& Tillage Research 79:7-31.

Six, J., S.M. Ogle, FJ. Breidt, R.T. Conant, A.R. Mosier, and K. Paustian. 2004b. The potential to mitigate global warming with no-tillage management is only realized when practiced in the long term. Global Change Biology 10:155-160.

Stöckle, C.O., M. Donatelli, and R. Nelson. 2003. CropSyst, a cropping systems simulation model. European Journal of Agronomy 18:289-307.

Stöckle, C.O., S. Martin, and G.S. Campbell. 1994. CropSyst, a cropping systems model: Water/nitrogen budgets and crop yield. Agricultural Systems 46:335-359

USDA ARS (Agricultural Research Service). 2004. The wind erosion prediction system, WEPS 1.0 user manual. Manhattan, KS: Wind Erosion Research Unit.

USDA NRCS (Natural Resource Conservation Service). 2002. Guide to using the soil conditioning index $\mathrm{ftp}$ //ftp-fc.sc.egov.usda.gov/SQI/web/SCIguide. pdf; software available at http://soils.usda.gov/sqi/ publications/publications.html\#sci.

USDA NRCS. 2006. Revised Universal Soil Loss Equation Version 2. http://fargo.nserl.purdue.edu/rusle2 dataweb/RUSLE2_Index.htm.

USEPA (Environmental Protection Agency). 2011. Inventory of US Greenhouse Gas Emissions and Sinks: 1990-2009. EPA 430-R-11-005.

Verberne, E.L.J., J. Hassink, P. de Willigen, J.J.R. Groot, and J.A. van Veen. 1990. Modelling organic matter dynamics in different soils. Netherlands Journal of Agricultural Science 38:221-238.

Van Hemelryck, H., P. Fiener, K.Van Oost, G. Govers, and R. Merckx. 2010. The effect of soil redistribution on soil organic carbon: An experimental study. Biogeosciences 7:3971-3986.

Van Hemelryck, H., G. Govers, K.Van Oost, and R. Merckx. 2011. Evaluating the impact of soil redistribution on the in situ mineralization of soil organic carbon. Earth Surface Processes and Landforms 36:427-438.

Van Oost, K., G. Govers, T.A. Quine, G. Heckrath, J.E. Olesen, S. De Gryze, and R. Merckx. 2005. Landscape- scale modeling of carbon cycling under the impact of soil redistribution: The role of tillage erosion. Global Biogeochemical Cycles 19:GB4014.

Van Veen, J.A., J.N. Ladd, and M.J. Frissel. 1984. Modelling C and $\mathrm{N}$ turnover through the microbial biomass in soil. Plant and Soil 76:257-274.

Van Veen, J.A., and E.A. Paul. 1981. Organic carbon dynamics in grassland soils. I. Background information and computer simulation. Canadian Journal of Soil Science 61:185-201

Wang, Z., B. Zhang, X. Li, K. Song, D. Liu, and S. Zhang. 2006. Using CropSyst to simulate spring wheat growth in black soil zone of northeast China. Pedosphere 16:354-361.

West, T.O., and W.M. Post. 2002. Soil organic carbon sequestration rates by tillage and crop rotation: A global data analysis. Soil Science Society of America Journal 66:1930-1946.

Whitmore, A.P., H. Klein-Gunnewiek, G.J. Crocker, J. Klír, M. Körschens, and P.R. Poulton. 1997. Simulating trends in soil organic carbon in long-term experiments using the Verbene/MOTOR model. Geoderma 81:137-151.

Wu, L., and B. McGechan. 1998. A review of carbon and nitrogen processes in four soil nitrogen dynamics models. Journal of Agricultural Engineering Research 69:279-305. 